\title{
Türk Gıda Sektöründe Marka Mirası Kavramı: İşletmeler Açısından Önemi (Brand Heritage Concept in Turkish Food Industry: Its Importance for Companies)
}

\author{
Hilal DOĞRUÖZ ÖZER iD a Elif AKAGÜN ERGİN \\ a Çankaya Üniversitesi, İşletme Bölümü, Ankara, Türkiye. c1676603@student.cankaya.edu.tr \\ b Çankaya Üniversitesi, İşletme Bölümü, Ankara, Türkiye. akagün@cankaya.edu.tr
}

\begin{tabular}{ll}
\hline MAKALE BİLGISİ & ÖZET \\
\hline Anahtar Kelimeler: & Amaç - Marka mirası, marka araştırmalarında gelecekteki önceliklerden biri olarak kabul \\
Marka Mirası & edilmektedir. Mirası olan markalar, ürünlerinin temel değerlerinin ve performansının güvenilir \\
Gıda Sektörü & olduğunun kanıtı olarak, uzun ömürlülük ve sürdürülebilirlik sahibidir. Gıda sektörüne odaklanan \\
Sürdürülebilirlik & bu makalede, marka mirasının oluşturulması ve sürekliliğinin sağlanması konusunda işletmelerin \\
Marka Yönetimi & önem verdikleri faktörlerin ve izledikleri yöntemlerin araştırılması amaçlanmıştır.
\end{tabular}

Yöntem - Çalışma, nitel araştırma desenlerinden biri olan durum çalışması (örnek olay) ile yürütülmüştür. Gıda sektöründe marka mirasına sahip işletmelerin temsilcileri ile derinlemesine

Gönderilme Tarihi 1 Mayıs 2021

Revizyon Tarihi 20 Haziran 2021

Kabul Tarihi 25 Haziran 2021

Makale Kategorisi:

Araştırma Makalesi görüşmeler yapılarak marka mirasını oluşturma ve sürdürülebilirliğini sağlama stratejileri konusunda sorular sorulmuştur. Toplam 12 firmanın temsilcisi ile görüşme gerçekleştirilmiş ve görüşme soruları, literatürde Mats Urde'nin marka mirası konusunda ortaya koyduğu beş temel bileşenden yararlanarak hazırlanmıştır. Verilen yanıtlar nitel veri analizi yöntemi olan içerik analizi ile MAXQDA 2018 programı kullanarak çözümlenmiştir.

Bulgular - Marka mirasına sahip firma temsilcilerinin, markalarını bir yaşam biçimi haline getirdiğ $i$ ve marka mirası kavramını Urde' nin belirttiği beş temel bileşen ile oluşturdukları ortaya çıkan temel bulgular arasindadir.

Tartışma - Marka mirası kavramı özellikle ülkemizde literatürde yeni yer bulmaya başlamış bir kavramdır. Yapılan çalışmalar incelendiğinde marka mirası alanında, tüketici değil de, yönetim bakış açısı ile hazırlanmış çok az sayıda araştırmanın var olduğu tespit edilmiştir. Bu nedenle, gerçekleştirdiğimiz çalışmanın ülkemizde stratejik marka yönetimi alanındaki literatüre önemli bir katkı sağlayacağı değerlendirilmektedir.

\section{ARTICLE INFO \\ Keywords: \\ Brand Heritage \\ Food Industry \\ Sustainability \\ Brand Management \\ Marketing}

Received 1 May 2021

Revised 20 June 2021

Accepted 25 June 2021

Article Classification:

Research Article

\section{ABSTRACT}

Purpose - Brand heritage is acknowledged as one of the future priorities in branding research. Heritage brands stand for longevity and sustainability, as proof that the core values and performance of the given products are reliable. Focusing on the food industry, the aim of the present study is to analyze the drivers and strategies of brand heritage from the viewpoint of management.

Design/methodology/approach - The study was conducted in the case study, one of the qualitative research designs. In-depth interviews were held with the representatives of the businesses that have a brand heritage in the food industry, and questions were asked about the strategies of creating and sustaining the brand heritage. A total of 12 in-depth interviews were carried out and interview scripts were prepared by using the five characteristics put forward on brand heritage literature by Mats Urde. In-depth interviews were analyzed with MAXQDA 2018 program with thematic analysis, which is a qualitative data analysis method.

Results - Among the main findings, it is noted that the managers of companies with brand heritage perceive their brands as a way of life and form the concept of brand heritage with the five characteristcs stated by Urde.

Discussion - The concept of brand heritage is a relatively new one in the literature, especially in our country. When previous studies are examined, it can be observed that there are very few studies in the field of brand heritage prepared from the management's perspective rather than consumers. For this reason, it is considered that the findings of our study will make a significant contribution to the literature in the field of strategic brand management in our country. 


\section{GİRIŞ}

Teknolojinin gelişimi ile birlikte tüketicilere sunulan ürün ve hizmet alternatifleri artmıştır. Tüketiciler seçimlerini yaparken dikkate alacakları bir takım kriter setine ihtiyaç duyarlar ve zihinlerinde oluşturdukları bu kriter setine göre kararlarını verirler. Bu nedenle markaların pazarlama stratejilerini oluştururken öncelikle tüketicilerin zihninde olumlu bir konumlandırma yapmış olmaları büyük önem taşımaktadır. Marka mirası kavramı bu nokta da önem kazanmakta ve pazarlama stratejisi olarak kullanılabilmektedir. Tüketiciler tanıdık, yıllardır piyasada yer alan markaları tercih etmekte ve yüksek fiyat ödeme istekliliğine sahip olabilmektedir.

Marka Mirası: Markanın geçmiş performansına, uzun ömrüne, temel değerlerine, tarihin önemine ve sembollerine olan inançların tamamıyla; markanın geçmişini, bugününü ve hatta geleceğini kapsar (Urde vd., 2007). Marka mirası konusundaki ilk kapsamlı çalışma 2007 yılında Urde, Greyser ve Balmer tarafından gerçekleştirilmiştir. Urde vd. marka mirasının; markanın geçmiş performansını, uzun ömrünü, temel değerlerini, sembolünü ve markanın tarihine yönelik inanışlarını kapsayan beş boyuttan oluştuğunu belirtmişlerdir. Wiedmann ve diğ., 2011 yılında marka mirasının, tüketicilerin tutum ve davranışlarındaki etkisini ortaya koyan, nicel bir çalışma yapmışlardır. Otomotiv markalarını ele aldıkları araştırmalarında marka mirasının belirleyicilerini ve sonuçlarını incelemişlerdir. Geliştirdikleri model, ileride yapılacak olan çalışmalar için başlangıç niteliğindedir.

Marka mirası konusunda ülkemizde yapılan çalışmalar otomotiv ve finans sektörleri bağlamında yapılmış olup, nicel yöntem kullanılmıştır. Yapılan çalışmalar tüketicilerin marka mirasına bakış açılarını ortaya koymak; bu anlamda satın alma niyeti, marka güveni, müşteri tatmini, marka sadakati gibi markanın farklı boyutları ile ilişkileri araştırılmışıı. Marka mirasına sahip şirket temsilcileri ile marka mirasını oluşturma ve sürdürülebilirliğini sağlama konusunda herhangi bir çalışma olmadığı tespit edilmiştir. Literatürdeki bu eksikliği tamamlama ve bundan sonra yapılacak çalışmalara öncü olması amacıyla bu çalışma tasarlanmıştır.

Ülkemizin marka mirasına sahip şirketleri araştırıldığında tarihi mirasa sahip şirketlerin büyük çoğunluğunun gida sektöründe olduğu görülmüştür. Gıda sektörü ülkemiz açısından Osmanlı'dan günümüze kadar gelebilmiş markaların varlığı, Ülkemizin kültürel miras öğeleri arasında yer alması vb. açılardan önem taşımaktadır. Türkiye Cumhuriyeti'nin 1923 itibariyle kurulmuş olması ve teknolojik gelişmelerin ilerleyen yıllarda yaşanmış olması sebebiyle kökleri Osmanlı dönemine dayanan gıda sektöründe yer alan işletmelerin ömrünün diğer sektörlere göre uzun olması anlaşılabilmektedir.

Gıda sektöründe marka mirasına sahip firmaların kullandıkları pazarlama ve marka stratejileri nelerdir? sorusu araştırmanın problemi olarak karşımıza çıkmaktadır. Çalışmanın amacı gıda sektörünün farklı kollarında faaliyet gösteren marka mirasına sahip firmaların marka mirasını oluşturma ve sürdürülebilirliğini sağlama süreci ile ilgili stratejilerini ortaya koymaktır.

\section{LITERATÜR TARAMASI}

Marka mirası konusundaki ilk kapsamlı çalışma 2007 yılında Urde, Greyser ve Balmer tarafından gerçekleştirilmiştir. Urde vd. marka mirasının; markanın geçmiş performansını, uzun ömrünü, temel değerlerini, sembolünü ve markanın tarihine yönelik inanışlarını kapsayan beş boyuttan oluştuğunu belirtmişlerdir.

Wiedmann ve diğ., 2011 yılında marka mirasının, tüketicilerin tutum ve davranışlarındaki etkisini ortaya koyan, nicel bir çalışma yapmışlardır. Otomotiv markalarını ele aldıkları araştırmalarında marka mirasının belirleyicilerini ve sonuçlarını incelemişlerdir. Geliştirdikleri model, ileride yapılacak olan çalışmalar için başlangıç niteliğindedir. Balmer (2013) "Kurumsal Miras, Kurumsal Miras Pazarlaması ve Toplam Kurumsal Miras İletişimi: Onlar Nedir? Onlara Ne Oldu?" çalışması, kurumsal mirasın gereklerini belirtmeyi ve tanıtmayı ve kurumsal miras pazarlamasını ve toplam kurumsal miras iletişim kavramlarını açıklamaktadır. Balmer ve Hudson (2013) “Kurumsal Miras Markaları: Mead’ in Geçmiş Teorisi” adlı çalışmalarında Kurumsal 


\section{H. Doğruöz Özer - E. Akagün Ergin 13/2 (2021) 1781-1799}

miras markalarının tüketicilere neden ve nasıl hitap ettiğini açıklamaktadır. Mead teorisinin şirkette kullanıldığı ilk çalışmadır. Çiftçi, Velioğlu ve Umut (2014) "Marka Mirası Kavramı ve Hizmetlerde Marka Mirasına Yönelik Bir Ölçek Değerlendirmesi" adlı makalelerinde, bankacılık sektöründe çalışma yürütmüşlerdir. Jonathan Schroeder, Janet Borgerson and ZhiyanWu (2015) "Marka Kültürü Yaklaşımı Çin Kültürel Miras Markaları" adlı çalışmalarında; marka stratejilerinde marka mirasını kullanan Shanghai Tang ve Shang Xia (Çinin lüks markaları) markalarını kullanmışlardır. Bargenda (2015) "Finans Sektöründe Kurumsal Miras Markaları: Kurumsal Mimarlığın Rolü” çalışması sonucunda farklılaşmış bir kurumsal mirasın pazarlama karmasına ve kurumuna önemli katkılar sağladığı sonucuna ulaşmıştır. Cooper ve Merrilees (2015) “Kurumsal Miras Markası Yönetimi: Kurumsal Miras Markaları Kurumsal Çağdaş Markalara Karşı" adlı çalışmaları ile farklılıkların belirlenmesi amaçlanmış; kurumsal miras markaları ve çağdaş kurumsal markalar mirası nasıl yönetiyor açıklanmıştır. Santos ve Balmer (2015) "Miras Markalaşması Oryantasyonu: Ach Davası. Brito ve Kurumsal ve Ürün Mirası Markaları" adlı makalelerinde şirket ve ürün arasında mirasa dayalı bir etkileşim olduğunu, kurumsal mirasın şirket ve ürün açısından benimsenme aşamalarındaki farklıları ortaya koymaktadır. Dion ve Borraz (2015) “Miras Markalarının Yönetimi: Lüks Endüstrisindeki Mağazalarda Miras Kutsallaşması" adlı çalışma ile miras markalarında yönetimi, yöneticileri, satış personelini analiz etmiş; miras konseptlerini, yerlerini inceleyerek marka mirasını katkılarını sıralamıştır. Cooper, Miler ve Berriles (2015) “Kurumsal Lüks Miras Markalarının Eski Haline Getirilmesi: Krizden Hüküm Sürme" adlı çalışmalarında tiffany ve burberry mağazalarının marka mirasını önce kaybedip sonra nasıl tekrar kazandıklarını analiz etmiştir. Balmer ve Chen (2017) “Kurumsal Miras Markaları, Arttırılmış Rol Kimliği ve Müşteri Memnuniyeti" adlı çalışmalarında Çin'in ünlü kurumsal miras markası Tong Ren Tang'a (TRT) yönelik müşteri memnuniyetini keşfetmeyi amaçlamıştır. Yıldız ve Koç (2017) “Marka Mirası ve Marka Güveninin Satın Alma Niyeti, Müşteri Tatmini ve Marka Sadakati Üzerindeki Etkileri" adlı çalışmalarını beyaz eşya sektörü özelinde yapmışlardır.

Markanın firmalara faydalarını Baş (2015) “Marka Yönetimi” adlı kitabında; markanın tutundurma bileşenine yardımcı ve talep yaratmada etkili olduğu, firma ve ürün imajının yerleştirilmesini sağladığı, firmanın satışlarını ve rekabet gücünü arttırdığı belirterek açıklamıştır. Ayrıca piyasada başarılı olmuş bir firmanın, kalite ile özdeşleşmiş bir markanın, ürün hattına yeni ürünler eklenmesini kolaylaştırdı̆̆ı, rakiplerinden farklı bir fiyat stratejisini takip etme imkânı sunduğu, aracı kuruluşların, o ürüne piyasa fiyatından farklı fiyat koymasını engellediği şeklinde özetlemiştir.

Aktepe C. ve Baş M. (2008) “Marka Bilgisi Sürecinde Marka Farkındalığı ve Algılanan Kalite (Beklenti) İlişkisi ve GSM Sektörüne Yönelik Bir Analiz" adlı çalışmalarında marka değerinin arttırılması için; marka yönetimi sürecinde tüketici odaklı davranma, tüketici ve marka arasında duygusal bir bağ kurma, markanın tüketiciler tarafından hızlı algılanması, verdiği sözü tutan bir marka olarak bilinmesi ve tüketiciye verilen mesajın tekrarlanması gerekliliğini vurgulamışlardır.

\section{YÖNTEM}

\subsection{Araştırmanın Modeli/Araştırma Sorusu}

Araştırmanın amacına yönelik olarak, nitel araştırma yöntemlerinden durum çalışması (vaka çalışması, case study) kullanılmıştır. Nitel araştırma yöntemlerinden biri olan durum çalışması, sosyal bilimler alanında çok fazla kullanılan araştırma yöntemlerinden biridir. Durum çalışması, bir olay veya durumu farklı bakış açıları ile değerlendirmek ve anlamak için yapılan çalışmalardır. Farklı rollerdeki kişilerin aynı olaydaki durum ve tutumları incelenerek durum hakkında daha detaylı bilgi üretilebilmektedir (Bogdan ve Biklen, 1998).

Durum çalışması modelinin en önemli özelliği; araştırmada ele alınan durumun, kişinin ya da topluluğun kendisine özgü özellikleri nedeniyle seçilmesi ve kendi bağlamı içinde ele alınmasıdır. Bu bağlamdan yola çıkarak durum çalışması; özel bir kişi, topluluk veya olayı incelemek için araştırmanın çalışma grubu olarak belirlenen katılımcıların tutum ya da davranışlarını ortaya çıkarmak ve bu özellik veya davranışların sistematik biçimde açıklanmasıdır. Bu özelliğinden dolayı durum çalışması; fenomenoloji, etnografik araştırma ve gömülü teori araştırması gibi bir nitel araştırma yöntemi olarak nitelendirilmektedir (Johnson ve Christensen, 2004). 


\section{H. Doğruöz Özer - E. Akagün Ergin 13/2 (2021) 1781-1799}

Bu çalışmanın araştırma sorusu; "Firmaların marka mirasını yönetirken kullandıkları pazarlama ve marka stratejileri nelerdir?" sorusudur. Araştırmanın amacı kapsamında, marka mirasına sahip firmaların marka mirasının yönetiminde ortak olarak ortaya koyduğu stratejilerine ilişkin görüşleri aynı araştırma sorularıyla farklı durumlarda cevap arandığından durum çalışması çeşitlerinden bütüncül (çoklu) vaka çalışması kullanılmıştır. Bütüncül vaka çalışması, benzer birkaç durumun ele alınarak sonuçların güçlendirilmesini ve genelleme yapılmasını sağlayan araştırma modelidir.

\subsection{Araştırmanın Evren ve Örneklemi}

Araştırmanın örneklemi, amaçlı örnekleme yöntemlerinden benzeşik örnekleme ile belirlenmiştir. Benzeşik örnekleme, birbirine benzer birey, grup, olay veya kurumların detaylı bir şekilde incelenmek istendiği durumlarda kullanılır ve genellikle benzer bireyleri içeren bir alt grubun oluşturulması tercih edilir (Patton, 2002). Araştırmanın örneklemini oluşturan firmaların ortak özelliği marka mirasına sahip firmalar olmasıdır.

Araştırmanın evreni belirlenirken, 50 yıllık Balmer (2013) kriteri önemli bir yaş işareti olarak kabul edilmiştir. Örneklem seçimi yapılırken firmanın 50 yıl üzerinde faaliyet gösteriyor olmasının yanı sıra gıda sektörünün farklı alanlarını kapsayacak şekilde firmalar belirlenmiştir. Ayrıca ülkemizde faaliyet süresi en fazla olan kurumsal firmalar listelenerek faaliyet süresinin uzun olması da bir seçim kriteri olarak ele alınmıştır. Çalışma kapsamında şirketin yaşam ömrü olarak en azı 95 yıllık, en uzunu 243 yıllık, 12 marka temsilcisi ile derinlemesine görüşme yapılmıştır. Gıda sektöründe faaliyet gösteren bu markalar lokum, akide, şekerleme, baklava, döner kebap, güllaç, helva, zeytinyağı, kebap, köfte, badem şekeri, kahve, kuru yemiş, helva, boza ve pasta gibi birçok ürün türünü kapsayacak şekilde belirlenmiştir. Görüşme yapılan markaların temsilcilerinin 11'i markanın sahibi, 1 kişi ise 27 yıldır çalışan yönetici pozisyonundaki kişidir. Araştırmanın çalışma grubunu oluşturan katılımcılar K1, K2,..., K12 şeklinde belirtilmiştir.

\subsection{Araştırmanın Veri Toplama Aracı}

Araştırmanın veri toplama aracı olarak marka mirasına sahip firmaların marka mirasının yönetiminde ortak olarak ortaya koyduğu stratejilerine ilişkin görüşlerin ele alındığı görüşme sorularının belirlenmesi ile ilgili literatür taraması yapılmış ve ayrıca alan uzmanlarının da görüşleri alınarak gerekli düzeltmeler yapılmıştır. $\mathrm{Bu}$ bağlamda araştırmanın veri toplama aracı marka mirasının kavramsal çerçevesini oluşturan 5 temel kavram üzerinden (Urde, 2007) oluşturulmuştur. Bunlar: marka geçmiş performansı, markanın uzun ömürlü olması, markanın temel değerleri, marka sembolü, marka tarihine yönelik inanışlardır. Literatürden yararlanılarak görüşme soruları oluşturulmuştur. Buna göre araştırmanın veri toplama aracını oluşturan görüşme formunda 8 yarı yapılandırılmış açık uçlu soru bulunmaktadır:

- Şirketinizin temel değerleri nelerdir?

- Kurumsal markanın özünü nasıl tarif edersiniz?

- Kurumsal markanın özünü korumak için özel olarak neler yapıyorsunuz?

- Markanın uzun ömürlü olmasını nasıl sağlıyorsunuz?

- Kurumsal markanın güçlendirilmesinde yenilikçiliğin rolü nedir?

- Markayı nasil güncel tutuyorsunuz?

- Güvenilirlik için aldığınız önlemler nelerdir?

- Markanızın sembolü, anlamı ve kurulduğundan beri değişiklik olup olmadığı konusunda bilgi verebilir misiniz?

Veriler derinlemesine görüşme tekniğiyle toplanmıştır. Bu görüşme tekniği, eğitim alanında en yaygın kullanılan görüşme türlerinden biridir. Birebir görüşmeler katılımcıların düşüncelerinin rahat ve açık bir şekilde ifade edilmesine olanak sağlayan ideal görüşmelerdir (Creswell, 2014). Araştırmanın verileri tüm dünyayı etkisine alan küresel salgın COVID-19 güvenlik önlemleri nedeniyle Zoom Meeting üzerinden Temmuz 2020-Şubat 2021 tarihleri arasında toplanmıştır. Görüşmeler ortalama yaklaşık 45 dakika sürmüştür.

\subsection{Verilerin Analizi}

Araştırmada elde edilen verilerin analizinde içerik analiz kullanılmıştır. Bu analizin amacı, elde edilen verilerin araştırma kapsamındaki kavramalara ve ilişkilere ulaşılmasını sağlamaktadır. Buna göre, birbirine benzeyen verileri belirli kavramlar ve temalar çerçevesinde bir araya getirerek, bunların okuyucunun anlayabileceği bir biçimde organize ederek yorumlanmasını sağlamaktadır (Yıldırım ve Şimşek, 2018:107). 
İçerik analizi, Thomas ve Hardene (2008) tarafından kullanılan analiz aşamalarına göre veriler nitel veri analiz programı MAXQDA 2018 kullanılarak yapılmıştır. Bu aşamalar aşağıda açıklanmıştır:

Bulguların Kodlanması: Bu aşamada birincil araştırmalardan çıkarılan doğrudan alıntılar ya da temel kavramlar şeklindeki bulgular, satır satır okunarak kodlanmaktadır. Bütün bulgular kodlandıktan sonra ikinci aşamaya geçilebilir.

Betimleyici Temaların Geliştirilmesi: Bu aşamada elde edilen kodlar benzerlik ve farklılıklarına göre karşılaştırılarak hiyerarşik bir ağaç yapısı oluşturacak şekilde gruplandırılır. Oluşturulan her gruba tema adı verilmektedir. Her tema, gruplanmış kodların tanımlarını ve anlamlarını kapsayacak şekilde oluşturulmaktadır.

Analitik Temaların Üretilmesi: Bu aşama, temaların geliştirilmesi sürecinde birincil çalışmaların bulgularına yakın kalınırken, analitik temaların üretilmesi sürecinde birincil çalışmaların ötesine geçilerek yeni yorumlayıcı yapılar ve açılamalar üretilmektedir. Birincil çalışmaların ötesine geçme, bir süreliğine askıya alman araştırma sorularının cevaplanması için tümevarımsal analiz sonucu elde edilen betimleyici temaların kullanılmasını gerektirmektedir. Bu amaçla betimleyici temaların karşılaştııılması ve başka araştırmacılarla tartışılması sonucu, daha soyut olan analitik temalar oluşturulmaktadır.

Geçerlik ve Güvenirliği Sağlama Aşaması: Bir araştırmanın bilimsel bir çalışma olarak kabul edilmesinde en önemli unsur güvenilirlik ve geçerliliğidir. Nitel araştırma tekniklerinde; toplanan verilerin ayrıntılı olarak incelenmesi, araştırmacının sonuçlara nasıl ulaştığını açıklamasında geçerliğin önemli ölçütleri arasında yer almaktadır (Yıldırım ve Şimşek, 2018).

Temalar ilgili literatüre dayalı olarak belirlenmiş, kodlar çıkartılmış ve nitel araştırmaya uygun bir içerik çözümlemesi yapılmaya çalışılmış ve bulgular sunulmuştur. Elde edilen veriler, çalışmanın amaçları doğrultusunda temalar ve alt temalar tanımlanarak analiz edilmiştir.

Bu çalışmada, elde edilen veriler, araştırmanın güvenirliğinin sağlanması için veriler iki uzman görüşüne başvurulmuştur. Miles ve Huberman (1994)'ın güvenirlik formülünden faydalanılmıştır. Formül aşağıda verilmiştir:

Güvenirlik = [Görüş Birliği / (Görüş Birliği + Görüş Ayrılıği) $]$ x 100

$$
=[170 /(170+15)] \times 100=[170 / 185] \times 100=[0,91] \times 100=91
$$

Miles ve Huberman (1994)'ın güvenirlik formülü sonucunda \%91 çıkmıştır. Miles ve Huberman (1994)'a göre \%70 ve yukarısında çıkan araştırma sonuçlarının güvenirliliğinin yüksek olduğunu belirtmişlerdir.

\section{BULGULAR}

Araştırmanın veri toplama araçlarından elde edilen bulgular ve değerlendirmeleri ayrı başlıklar altında ele alınmıştır. Bulgularda yer alan tema başlıkları Taşkın Ç. (2018) “Marka ve Marka Stratejileri” ve Koç. E. (2017) "Temel Tüketici Davranışı ve Pazarlama Stratejileri" kitaplarından yararlanılarak ifade edilmiştir.

\subsection{Katılımcıların Şirketin Temel Değerleri Hakkındaki Görüssleri}

Araştırmanın çalışma grubunu oluşturan katılımcıların şirketin temel değerleri hakkındaki görüşleri Tablo 1 'de verilmiştir.

Tablo 1. Katılımcıların Şirketin Temel Değerleri Hakkındaki Görüşleri

\begin{tabular}{|l|l|l|l|l|}
\hline Kategori & Olması Gereken Değerler & & İstenilen Değerler & \\
\hline \multirow{4}{*}{} & Tema & f & Tema & f \\
\cline { 2 - 5 } & Etik Değerler & 8 & Marka Mirasını ve Değerini Korumak & 3 \\
\cline { 2 - 5 } & Sosyal Sorumluluk Bilinci & 3 & & \\
\cline { 2 - 5 } & Müşteri Odaklılı & 7 & & \\
\cline { 2 - 5 } & Duyarlılı & 6 & & \\
\cline { 2 - 5 } & Şirket Gelenekleri & 6 & & \\
\cline { 2 - 4 } & Yenilik Stratejileri ve Yönetimi & 1 & & \\
\hline
\end{tabular}




\section{H. Doğruöz Özer - E. Akagün Ergin 13/2 (2021) 1781-1799}

Tablo 1.'e göre katılımcların şirketin temel değerleri hakkındaki görüşleri bir bütün olarak ele alındığında işlev ve kavram yönüyle iki kategori olarak değerlendirilmiştir. Bu kategoriler; Olması Gereken Değerler (31) ve İstenilen Değerler (3)'dir.

Olması Gereken Değerler (31) kategorisinin temalarına ait katılımcı cevaplarından bazı örneklere aşağıda yer verilmiştir:

"Bizim şirketimiz bir anonim şirket, ticaret yapılan bir yer ama bizde her zaman şu misyonda olmuştur; bu ülkenin bir değeriyiz yani her satıştan kar sağlamaktan ziyade bu şekeri tanıtmalı insanları her zaman bu işin içine katmak bizde sırf şekerde değil bayramın kendisi, bayram adetleri, kız isteme adetleri, mevlitler. Çocuk partileri çok daha revaçtayken biz onlara özel bir şey üretmedik. Mevlit sonuçta insanları anmak için yapılan bir etkinlik... Bizim tek amacımı bir ürün alıp satmak değil bu kültürü tanıtmak bu ülkenin bir değerini tanıtmak amacımız."(Sosyal Sorumluluk Bilinci) (K1)

“Bizim 130 TL'e de lokumumuz var, 35 TL'e de lokumumuz var. Her bütçeye uygun can isteyen herkesin ulaşımına açık. Ulaşılabilirlikte bizim için önemli. Müşterinin fiyat yüzünden dükkândan eli boş çıkması bizi hep mutsuz etmiş. Dolayısıyla sade lokumu daha az karlı satarı biz bu konuda duyarlıyız... Müşteri geri bildirimi de bizim için çok önemli. Çok güzel geri bildirimler gelebiliyor." (Müşteri Odaklılık; Duyarlılık) (K1)

"Bir gelenek olmazsa olmaz iki yenilik olmazsa olmaz. Şirket genelde zıtlıkları içinde barındıran bir şirket. Hep gelenek üzerine kurulu bir düzen var. Oradan oraya babadan oğula gibi bir anlayış vardı aslında bu da kırıldı artık... Bu da bu işin bir yeniliği, bugünkü şart bu ise biz buna uyum sağlayacă̆ız. Marka seçecekken bunlar bu işi bu kadar uzun zamandır yapıyorsa doğru yapıyordur diye düşünerek güven hissi yaratabilir... Her nesilde tespit ettiğimiz yenilikler var. Yenilik ve gelenek hep birlikte ilerledi bu ikisinin kesişimi de aslında kültür. Biz aslında geleneksel baklavacilığr yenileyerek geleceğe taşımaya çalışıyoruz." (Şirket Gelenekleri; Yenilik Stratejileri ve Yönetimi) (K2)

“...terbiye, ahlak, iş ahlakı da bunun içerisinde olan, etik anlayış temel değerlerimiz. İşimizi biliriz ama işimizden daha iyi bildiğimiz bir şey var haddimiz. İnsan işinin içerisine sevgisini, emeğini her şeyini koyduğu zaman başarıya ulaşabilir" (Etik Değerler) (K3)

"Ben şuna da inanıyorum markalar aileler ile bütünleşiyor. Yani ailenin duruşu, dürüstlü̈̆̈̈, çizgisi, davranışı o da markaya yansıyor. Babası 30 yıla yakındır burada çalışıyor. Dolayısıyla burada birçok çalışanlarımızın çocukları, yeğenleri, amca, dayı çocukları çalışıyor böyle de bir aile gibiyiz. Bunu çok önemsiyorum. Bunu da şuradan biliyorum Japonların Kaizen Modelinde, Toyota da mesela derlermiş ki dedem burada çalıştı, dedemin dedesi burada çalıştı, babam burada çalıştı. Bizde de öyle oldu, bu da ayrı bir bütünlük. Kurduğunuz şehri yansıtıyorsunuz." (Şirket Gelenekleri; Etik Değerler) (K4)

"Şirketimizin temel değerleri; paylaşımcı olmamız, açıklık ilkesi, yeni kuşakların önünün açılması, itibar sahibi olmak, kaliteyi sürekli hale getirmek bir de markanın 6. ve 7. kuşaklara kadar iletilmesini sağlamak... Bosh'un söylemine baktığımızda 'itibarımı kaybettiğimde her şeyimi kaybederim' mantığı ile bizde itibarımızı en önde tutarak bütün her şeyi paylaşım ve açıklı üzerine kurmaya çalışıyoruz. Yeni kuşakların önünün açılması da bizim temel değerlerimizin arasında. Çünkü burada 100 yıla gelen bir markanın sorumluluğu ciddi bir sorumluluk yaklaşımım var." (Şirket Gelenekleri; Etik Değerler) (K6)

"Çekirdekten gelme olduğunuz zaman ve markanızın bu kadar yaşadığın düşündüğ̈̈̈nüz zaman zaten siz lezzetli ve doğru, insanların damakları ile barışık bir tad yapıyorsunuz, oradan kurtarmışsınız. Bunun üzerine ne ekleniyor? Sürekli iş ahlakı, disiplin, dürüstlük. Mesela büyüklerimizin bize hep şunu söylerdi: 'Oğlum hiçbir zaman sizin yemediğiniz, yiyemediğiniz, kendi ă̆zınıza layık görmediğiniz hiçbir şeyi mutfağınıza, tezgâhınıza, satış yerinize sokmayın'. Bizim için en önemli değer dürüstlük diyebilirim. Şimdi şöyle düşünün ar-ge çalışması diyorlar şimdiki adıyla, aslında biz o çalışmaları yaptığımız zaman yeni oluşan markalardan biz çok çok dezavantajlıyız. Aslında bu devavantaj değil bize değer katıyor ama masaya oturduğunuz zaman siz eğer bir marka mirasında mirasçıysanız, bizim düşündüğümüz şöyle herkes ne düşünür önce ürünü üretmek, pazarlamak ve kar etmek. Ama biz ne düşünüyoruz: ürünü üreteceğiz tamam da ama bizim markamı çok önemli bir marka, paradan önce kardan önce isme bir zarar gelmesin diye düşünürüz. Şahsi kimliğimizden ziyade ilk önce markanın değerlerini düşünüyoruz." (Şirket Gelenekleri; Etik Değerler; Sosyal Sorumluluk Bilinci) (K7)

"Tabi ki her şirketin olduğu gibi bizde de insan odakh olmak, doğruluk, güvenilirlik. Bunlar bizim için olmazsa olmaz kurallarımızdan bir tanesi. Bunun için istikrar, güvenilirlik gerekiyor. Tedarikçilerinizle olan ilişkilerimiz de bu şekilde diyebilirim." (Müşteri Odaklılık; Duyarlılık; Etik Değerler) (K8) 
“Temel prensibimiz ürünün kalitesi. Ürünü müşteriye kaliteli sunmak mecburiyetindeyiz....ikkincisi çalışanlarınızı yetiştirme anlamında bir değere sahibiz. Çünkü bu bir bayrak yarışı bir ustanın kendinden sonrakini yetiştirmesi işin zekâtı olarak görüyoruz.... Üçüncüsü piyasada sürekli doğru iş yapacaksınız. Sözünüzü zamanında yerine getireceksiniz. Söz senettir. Bunu sürdürülebilir hale getirmek gerekiyor. Bizim ismimiz olduğu zaman herkes tamam der, hiç bir şey sormaz." (Müşteri Odaklılık; Duyarlılık; Etik Değerler) (K9)

"Şirketimizin temel değeri aslında kalite. O lezzeti, kaliteyi koruyabilmek. Bu kadar uzun süredir herkesin sevmesi, işletmemize gelen yaşlı insanların ben küçükken de gelirdim tadı hala aynı demesi bence bu markanın bu kadar senedir işlemesini sağlayan bir şey. Bu yüzden üç kuruş beş kuruş için kaliteyi bozmak orda yüz yıllık markanın ismini lekeleyecektir." (Müşteri Odaklılık; Duyarlılık; Etik Değerler) (K10)

"Bizim ana maddemiz öncelikle biz işimizin başındayız. Bizim başarımızın en büyük sebebi işimizin başında olmamız. Diğer temel değerimiz kaliteden asla ödün vermiyoruz. Bu bir kültür bu bir miras. Bugün biliyorsunuz Türkiye'de hakkaten çok az sayıda kaldı. Yüz Yillık Markalar Derneği ile de irtibat halindeyiz....Dediğim gibi kaliteden ödün vermediğimiz sürece ve işinde başında olduğumuz sürece mirasımız devam ediyor. (Şirket Gelenekleri; Müşteri Odaklılık; Duyarlılık; Etik Değerler) (K12)

İstenilen Değerler (3) kategorisinin temalarına ait katılımcı cevaplarından bazı örneklere aşağıda yer verilmiştir:

"Bizim en büyük mal varlığımız markamız. Markamızın korunması noktasında da o hareketi yaparak aslında 'en iyi defans ofanstır' derler ya biz ofansa girerek defans yaparak en iyi ofansımızı yapıyoruz. İnsanlar satüre olmuş bir pazarda ayırt etmede ve seçmede çok daha iyi kararlar alabiliyorlar. Çünkü bilgi çă̆ında yaşıyoruz. Şu sokakta ya da bu sokakta olmaniza gerek yok, iyiyseniz insanlar oraya geliyorlar...." (Müşteri Mirasını ve Değerini Korumak) (K3)

“...ailenin geçmişinde üretim kültürü var marka ailede her şeyden önce gelir. Biz Türkiye'nin yağ fiyatını belirleyen firma olmak istiyoruz. Çok satmak gibi bir derdimiz yok; en kaliteli en düzgün en uygun fiyata satmak gibi bir derdimiz var. Bu bir marka hassasiyetidir. Marka yaşanır, marka yaşatılır. İnşallah nesiller boyu markalarımız devam eder."(Müşteri Mirasını ve Değerini Korumak) (K4)

"Temel değerleri bu zincir halkasının devam ettirilmesi, Osmanlı ve Türkiye Cumhuriyeti'nin yemek kültürünü bütün dünyaya yaymaktır. Tüm Dünya'ya Osmanlı ve Türk yemeklerini tanıtmak. Hem de ecdadımızın yadigârı olan kültürü yaşatmak." (Müşteri Mirasını ve Değerini Korumak) (K11)

\subsection{Katılımcıların Kurumsal Markanın Özünün Tarifi Hakkındaki Görüşleri}

Araştırmanın çalışma grubunu oluşturan katılımcıların kurumsal markanın özünün tarifi hakkındaki görüşlerine ait bulgular Tablo 2.' de verilmiştir.

Tablo 2. Katılımcıların Kurumsal Markanın Özünün Tarifi Hakkındaki Görüşleri

\begin{tabular}{|l|l|l|l|l|}
\hline Kategori & Tüketici Temelli Marka Özü Tarifi & & Pazarlama Temelli Marka Özü Tarifi & \\
\hline & Tema & f & Tema & f \\
\hline & Marka Bilinirliği (6) & 6 & Ar-Ge Stratejisi (5) & 5 \\
\hline & Algilanan Kalite (8) & 8 & Popüler Kültür Stratejisi (2) & 2 \\
\hline
\end{tabular}

Tablo 2.'ye göre katılımcıların kurumsal markanın özünün tarifi hakkındaki görüssleri bir bütün olarak ele alındığında işlev ve kavram yönüyle iki kategori olarak değerlendirilmiştir. Bu kategoriler; Tüketici Temelli Marka Özü Tarifi (14) ve Pazarlama Temelli Marka Özü Tarifi (7)'dir.

Tüketici Temelli Marka Özü Tarifi (14) kategorisinin temalarına ait katılımcı cevaplarından bazı örneklere aşağıda yer verilmiştir:

"Hala özümüzden kopmadan lokumu, akideyi hala orijinal (geleneksel) reçeteye uygun olarak bu kültürü tanıtmayı ve insanlara sunmayı hedefleyen bir marka anlayışımız var." (Marka Bilinirliği; Algılanan Kalite) (K1)

"K3 sadece bir yemek bir restoran markası değildir. Bizler artık tarihin, kültürün hem de gastronominin üçünün de buluştuğu bir noktada olan bir marka. Deneyim markası. Çünkü bir yere gittiğiniz zaman buranın en iyisi diye sorduğunuzda, markayı kim alıyor? Benim müşterim kimse ben de oyumdur aslında. Ben burada ne kadar tarihini, kültürünü, 150 yıl önce büyük dedelerimin başlattığını anlatabilirim. Tabi ki çok önemli bir kısmı ama müşterinin gelme 
H. Doğruöz Özer - E. Akagün Ergin 13/2 (2021) 1781-1799

sebeplerinden birisi de o." (Marka Bilinirliği; Algılanan Kalite) (K3)

"Markanın özü doğruluk, dürüstlük, kalite, geri bildirimde anında cevap verebiliyor olmak, müşteri isteklerine cevap verebiliyor olmak..." (Marka Bilinirliği; Algılanan Kalite) (K4)

"Markanın özünü neler oluşturuyor derseniz. Evet gerçekten bir anonim hafiza var..." (Marka Bilinirliği) (K5)

"Bizimle ilgili her zaman şunu duyarım, özümüzü şöyle özetler tüketici, markamızı sevenler: "bir şey alacaksan, damak tadın seviyorsan $\mathrm{K} 7$ firmasından al. Belki bir iki lirası fazladır ama gönlün rahat hem lezzeti açısından hem hijyeni açısından hem çalışma sistemi açısından oraya git oradan al belki bir lirası fazladır ama lezzetli, kaliteli ürün alırsın". Özümüz şu; doğru, lezzetli ve temiz ürün üretip hiç kimseyi kandırmaya yönelik bir iş yapmadığımızdır." (Marka Bilinirliği; Algılanan Kalite) (K7)

"Marka özü sadece bir isimden, bir reklamdan, bir logodan olmuyor. Orada bir yaşanmışlık var, bir geçmiş var. İşte burada az önce bahsettiğiniz gibi sembol olan şeyler var. Bize ait imza yemekler var. Bunlar bütün halinde düşünülebilir. Burada tüketicinin kendisi öne çıkıyor. Tüketiciye göre esasen uzun ömürlü ayakta kalabilmemizi sağlayan faktörlerden bir tanesi. Marka özünde en etkili faktör tüketici. Markayı marka yapan tüketicidir." (Marka Bilinirliği) (K8)

"Ürünümüzün en temel özelliği içerisinde hiçbir katkı maddesi olmaması...ilk günkü hali ne ise o hali ile yola devam ediyoruz. O yüzden bizim için hala kıymetli ve lezzetli özü bu." (Algılanan Kalite) (K9)

“Bizim üretimimiz, seri üretim olan bir ürün değil. Imalathanede ustalara bağgl ürünün tadı kalitesi. Aslında biraz da müşterilerin yorumlar da tarifi değiştirmemize sebep oluyor...Asıl markanın özü müşteri memnuniyetidir; belli bir reçeteden ziyade müşteriden gelen geri bildirimler önemlidir." (Algılanan Kalite) (K10)

"Marka babadan oğula değil, usta çırak geleneğine göre gelmiş. Bizim tüm amacımız biz 4 arkadaşız markayı devam ettirebilmek ve başarılı bir şekilde sürdürebilmek. Gevşettiğin zaman kaybolur gider. Markanın özü özünü koruyan kaliteden ödün verilmeyen Osmanlı yemekleri." (Marka Bilinirliği; Algılanan Kalite) (K11)

"Kaliteden ödün vermiyoruz. Bizim aldığımız ürünler kaliteli ürünler..." (Algılanan Kalite) (K12)

Pazarlama Temelli Marka Özü Tarifi (7) kategorisinin temalarına ait katılımcı cevaplarından bazı örneklere aşağıda yer verilmiştir:

"Bizim markamızın, yaptığımız işin özü bu coğrafyaya has lezzetleri modern çağın gerekliliklerine ve trendlerine adapte ederek günümüze getirmek..." (Ar-Ge Stratejisi; Popüler Kültür Stratejisi) (K1)

“...değişime cevap verebiliyor olmak." (Ar-Ge Stratejisi) (K4)

"Temel değerler sabırlı olarak, geliştirerek, yaşayarak zorlukların üstesinden gelmek anlamında özetlenebilir." (Ar-Ge Stratejisi) (K5)

\subsection{Katılımcıların Kurumsal Markanın Özünü Korumak İçin Özel Olarak Yapılanlar Hakkındaki Görüşleri}

Araştırmanın çalışma grubunu oluşturan katılımcıların kurumsal markanın özünü korumak için özel olarak yapılanlar hakkındaki görüşlerine ait bulgular Tablo 3.'te verilmiştir.

Tablo 3. Katılımcıların Kurumsal Markanın Özünü Korumak İçin Özel Olarak Yapılanlar Hakkındaki Görüşleri

\begin{tabular}{|l|l|l|l|l|}
\hline Kategori & Tüketici Temelli Stratejiler & & Pazarlama Temelli Stratejiler & \\
\hline & Tema & f & Tema & f \\
\hline & Müşteri Deneyimleri & 3 & Organizasyonel Marka Stratejileri & 4 \\
\hline & Marka İmajı & 5 & Geleneksel İşletme Marka Stratejisi & 4 \\
\hline & Müşteri Odaklılık & $\mathbf{3}$ & & \\
\hline
\end{tabular}

Tablo 3.'e göre katılımcıların kurumsal markanın özünü korumak için özel olarak yapılanlar hakkındaki görüşleri bir bütün olarak ele alındığında işlev ve kavram yönüyle iki kategori olarak değerlendirilmiştir. Bu kategoriler; Tüketici Temelli Stratejiler (11) ve Pazarlama Temelli Stratejiler (8)'dir.

Tüketici Temelli Stratejiler (11) kategorisinin temalarına ait katılımcı cevaplarından bazı örneklere aşağıda yer 


\section{H. Doğruöz Özer - E. Akagün Ergin 13/2 (2021) 1781-1799}

verilmiştir:

“Biz müşteri geri bildirimine çok önem veren bir kurumuz. Gerek üretim olsun gerek satış olsun...Geri bildirim sistemi, kalite sistemi bu konuda çok önemli. Ama müşteriyi dinleyelim, üretim yaptığımız diğgr firmalar dinleyelim derken işin özünden çıkacağımız noktalar var ise o konularda biraz hassasız..." (Müşteri Deneyimleri) (K1)

"Ürünün doğasına aykır olmayan her şeye okeyiz. Ama daha karl diye daha çok ilgi çekiyor diye bizimde bilmediğimiz, daha önce bulunmadığımı alanlara girmek bizim tarzımı değil. Çünkü bugüne kadar bu çerçevede gelmiş bir firma ve kültür." (Marka İmajı) (K1)

"Kömürü hala ayn ocakta yıkıyoruz, yaz domatesini kullanıyoruz vb. bunlar hep hikâye gibi geliyor olabilir. Çünkü çok önemli şeyler....Büyüklerimden gördüğüm özellik, prensiplerimizden asla şaşmamak. Çünkü insanlar oraya yeni bir şey denemeye gelmiyor. O eski duyguların pekiştirmek için eski anılarını canlandırmak için o eski değerlerini yaşamak için geliyor... Bizler prensiplerimizden çıkmıyoruz ama prensiplerimizden çıkmamamızda aslında bize tamamen gönülden bağlı olan sadık müşteriye de borç biliyoruz." (Marka İmajı) (K3)

“Çok ince işler sizin görmediğiniz bir ince hata öyle bir tesir eder ki toparlayamazsını, yerleşir gider o yüzden bir ürün çıkarken onlarca defa test ediliyor, ön test yapılıyor, insanlara sunuluyor, evde kullandırllyor.. Çok farklı bir süreç. Sürekli geri bildirimlere açı olmak. Tüketicinin sorularının hiç birisi cevapsız kalmamalı. O mutlaktır bir markanın gelişmesinde malumunuzdur bir iyi söz 8 kişiye tesir eder, bir kötü söz 11 kişiye tesir eder. Bir hataya tahammülümüz yok. İyi bilmeli, eksik varsa erdem olan özür dilemektir." (Müş̧teri Odaklılık) (K4)

"Marka çok farkh bir şey sizinle bütünleşiyor...Burada şöyle bir şey oldu. Konya hızl tramvay kullanılan ilk şehirlerden birisidir. Ilk zamanlar 16 tramvay vardı biz tramvayın 16'ın da K4 yapmışık, hepsi K4 olmuştu. Kardeşim o zamanlar demişti ki belediyeye karda yağmurda iki gündür yıkanmamış izin verir misiniz biz yıkayalım. Gidip yıkatmışıı K4 yazılarını. K4 yazısı bir yere sürtmüş yırtılmış ona bile tahammülümüz yoktu. Başka bir örnek reklam yapmışız markette vb. reklamın görüneceği ampul patlamış gece gidilir, o florasan değiştirilir. Yeter ki K4 doğru yansın, eksik yanmasın. Bunlar büyük hassasiyetler. Marka her şeyimizdi biliyorduk ki o büyürse biz büyüyeceğiz." (Marka İmajı) (K4)

"Öncelikle güvenilir olmak yani gerçekten gelen misafirlere bir güven vermek. Onun dışında deneyim, imaj bunların hepsi önemli. Tarifler aynı, usta çırak ilişkisi şeklinde. Müşteri memnuniyetimiz aynı şekilde devam ediyor." (Marka İmaj1; Müşteri Deneyimleri) (K8)

"Müşteriye kötü mal vermek yerine o malı çöpe atmaya razı oluruz. Bu tarz hareketler de özünü korumak için önemlidir. Dükkâna yüzlerce kişi gelip gidiyor çalışanlar yoruluyor, stres oluyorlar. Bazen tartışmalar oluyor. Müşteri her zaman haklıdır, tamam deyin, geçin diye personele tembihlesek de insanlık hali oluyor bazen tartışma. Bir keresinde şöyle bir olay olmuştu, bir kişi bir personelimize küstü̈̆̈̈ için boza almayı bıraktı. Öyle bir tartışma olmuş. Babam o kişiyi gitmiş, bulmuş, konuşmuş, özür dilemiş." (Müşteri Odaklılık) (K10)

“Ustalarımız en az 40 senelik. Ustalarımızı çocukluktan yetiştirdik biz. Markanın özünü korumak adına biz hiçbir zaman fabrikasyon ürün üretme yoluna gitmiyoruz. K12'i K12 yapan tek şey 'tek merkez, tek kalite ve tek usta' ondan dolayı bu bizim için çok önemli. Kısa yoldan bende zengin olayım diye düşünseydik bana yurtdışından sayısız teklif geliyor. Franchisetn verelim, ortak olalım, şunu yapalım, bunu yapalım gibi. Biz parasal yönüne bakmıyoruz. Ondan dolayı içimiz rahat. Ürünümüzün kalitesi iyi olsun zaten çok fazla ürüne girmiyoruz tek çeşit ürünümüz var. Ürün ve kalite bozulmasın. Ona gidiyoruz. Ondan dolayı kaliteden ödün vermeme adına onlarla bu sisteme devam etmeye çalışıyoruz." (Marka İmajı) (K12)

Pazarlama Temelli Stratejiler (8) kategorisinin temalarına ait katılımcı cevaplarından bazı örneklere aşağıda yer verilmiştir:

"Logomuz olsun, işletmemiz olsun, yenilerken re-branding denilen çalışmalarn yapıyoruz ama her zaman bir öncekine paralellik kuracak özünü değiştirmeyecek yani bir günden bir güne önünden geçen insanın tanımayacağı hale gelmeyecek, yiyen insanın tanımayacağı hale gelmeyecek şekilde bunu yapmaya çalışıyoruz." (Organizasyonel Marka Stratejileri) (K1)

"Ne zaman formülün dışına çıkmaya başladığınızda başarısızlık oluyor. Ülkenin siyasi görüş olabilir, savaş olabilir işte bu korona olabilir vb. bazı şeylerin değişmediğini görmek insanları sakinleştirebiliyor. Bizim markamızın özelliklerinin de birisinin de bu olduğunu düşünüyorum." (Geleneksel İşletme Marka Stratejisi) (K3)

"Çok alan değiştirmeyi seven bir şirket yapımız yok....Yine tersinden aynı sektörde kazancı olan biz gıdacıları ele 
H. Doğruöz Özer - E. Akagün Ergin 13/2 (2021) 1781-1799

aldığımızda, bu işimizden bir şeyler kazandık bir sermaye elde ettik bunu mümkün olduğunca ayn sektöre yatırılması gerektiğini düşünenlerdeniz. Markanın özünü korumayı da ben buraya bağlıyorum. Dağılmamak gerekir tersine odaklanmak gerekir... Neden çünkü odaklanınca karlılı̆̆ı yakalamak için yaptığınız şeyleri gördünüz. Bu örnekten yola çıkarak marka özünü korumayı çok detaylarla uğraşmaktan kurtularak mümkün olduğu kadar daha kolay yönetilebilir ürünlere kaymak lazım. Ama bu başka bir sektöre kaymayı getirmemesi lazım. İi bildiğiniz işi yapmalısını diye düşünüyoruz." (Geleneksel İşletme Marka Stratejisi; Organizasyonel Marka Stratejileri) (K6)

“...Siz markaysaniz ve tüketicinin beklentisi sizden yüksekse inanın ki bir hatanız olur bakın yanlış demiyorum hata günümüzde maille, sosyal medya hesaplarımızda mutlaka size iletilen ama inanın ikinci şansınız aynı insan için yok onun için özünüzü korumak için hammadde alımından sofralara gidene kadar her şeyin başında olmanı ve kontrolünün elinizde olması lazım." (Geleneksel İşletme Marka Stratejisi) (K7)

"Sanatsal, kültürel etkinliklerde yakından ilgilenmek, bulunmak. Markayı bu şekilde daha sağlam şekilde ayakta tutmaya çalışıyoruz." (Organizasyonel Marka Stratejileri) (K8)

"Ürünün oluşumuna etki eden malzemelerin kalite kontrolünü yapıyoruz. Ana noktadan dağıtım yapıyoruz 53 yere." (Geleneksel İşletme Marka Stratejisi) (K9)

"Marka özünü korumak kolay olmuyor. Adam yetiştiremiyoruz. Bizde çalışanlar öyle günü birlik değil en az 30 sene 40 sene 50 sene başarll, mesleğine önem veren değer veren kişiler emekli olana kadar bizde devam ediyorlar. Hem kendine hem çalıştığı müesseseye faydalı olayım diye düşünüyorsa o zaman bizden ayrılmaz devam eder. Şu an çalışanlarımız en az 47 yıllık." (Geleneksel İşletme Marka Stratejisi) (K11)

\subsection{Katılımcıların Markanın Uzun Ömürlü Olması İçin Yapılanlar Hakkındaki Görüşleri}

Araştırmanın çalışma grubunu oluşturan katılımcıların markanın uzun ömürlü olması için yapılanlar hakkındaki görüşlerine ait bulgular Tablo 4.'te verilmiştir.

Tablo 4. Katılımcıların Markanın Uzun Ömürlü Olması İçin Yapılanlar Hakkındaki Görüşleri

\begin{tabular}{|l|l|l|}
\hline Kategori & Fonksiyonel Stratejiler & \\
\hline \multirow{4}{*}{} & Tema & f \\
\cline { 2 - 3 } & Ar-Ge Stratejisi & 3 \\
\cline { 2 - 3 } & Pazarlama Stratejisi & 1 \\
\cline { 2 - 3 } & Organizasyonel Marka Stratejisi & 5 \\
\cline { 2 - 3 } & Marka Yerleştirme Stratejisi & 1 \\
\cline { 2 - 3 } & Marka Yayma Stratejisi & 1 \\
\cline { 2 - 3 } & Marka İsim Stratejisi & 6 \\
\hline
\end{tabular}

Tablo 4.'e göre katılımcıların markanın uzun ömürlü olması için yapılanlar hakkındaki görüşleri bir bütün olarak ele alındığında işlev ve kavram yönüyle bir kategori olarak değerlendirilmiştir. Bu kategori; Fonksiyonel Stratejiler (17)'dir.

Fonksiyonel Stratejiler (17) kategorisinin temalarına ait katılımcı cevaplarından bazı örneklere aşağıda yer verilmiştir:

"Ben altıncı kuşağım. Sektör buna müsait bir sektör. Gıda dünyanın her tarafında en çok tercih edilen sektör....Ama benim ailemin gördüğ̆̈̈ firsat şu ki Avrupa'daki gelişmeleri takip edebiliyorlar. Bu da... bir çı̆̆ır açmaları kalıcılıkların kolaylaştırmış. Hem üretimi hem tüketimi kolaylaştırıcı bir elementi eklemeleri bu sürekliliği sağlamış." (Ar-Ge Stratejisi) (K1)

"Ülkeler değişiyor, satışlar değişiyor ama dünya da her ülkeden talep var. İhracatı çok kolay bir ürün. Hayvansal gıda yok beklemesi kolay." (Pazarlama Stratejisi) (K1)

"Genel anlamda adaptasyon derim. Aslında adaptasyon biraz geri de kalyyor gibi çevrenizde bir şeyler oluyor siz uyum sağhlyorsunuz gibi... Adaptasyondan da ziyade önceden öngörüp öncüsü olmak. Bir işin öncüsü olmak kolay bir şey de değil çok tepki de alabilirsiniz...Müşteri sadece orada değerlendiricidir. Yoksa müşterinin öncülü̈̆̈̈ olsa AR-GE birimleri de olmazdı. Orda onu hissedip yapmak bizim markamızın da farkı bu. Peşinden ne kadar sürüklediğinle de alakah bir şey. Oyunun kuralların değiştirmek istiyorsanı oyunun kuralların çok iyi bilmeniz gerekiyor. Oyunun kuralın bilmeden 


\section{H. Doğruöz Özer - E. Akagün Ergin 13/2 (2021) 1781-1799}

paradigma kırılmaz. Paradigmanın içine doğmuşsunuzdur, paradigmanın her şeyini biliyorsunuzdur. Bu şekilde paradigmayı kırabilirsiniz. Geleneğe sahip çıkarak gelenek değişir aslında, geleneğe karşı durarak değil geleneği içine alarak değiştirirsiniz. Çünkü zaten peşinizden öyle gelir insanlar." (Ar-Ge Stratejisi; Organizasyonel Marka Stratejisi) (K2)

“...sakinleştirici özelliğini, kaos olduğu zaman evinize geldiğinizdeki o huzur. Sakinleştirici özelliğimiz sizinle konuşurken ortaya çıtı. Çünkü bazen bazı şeyler konuşurken ortaya çıkar. Devamlılığını koruma anlamında da siz doğru soruları sorduğunuz ve sormayı planladığını için hepsi birbirine geçmiş durumda" (Organizasyonel Strateji) (K3)

"Marka ile bütünleştik onu yaşam şeklimiz haline getirdik." (Marka Yerleştirme Stratejisi) (K4)

"Sabır, tarihi bir mirası taşıyor olmanın sorumluluğu, gelenek, kuşaklar arası aktarım. Markamızın uzun ömürlü olmasının sebeplerinden bir tanesi toplumsal hafiza olduğu kadar işin yapılış biçimi ile alakalı..." (Marka Yayma Stratejisi) (K5)

"...Gerçekten de iş oradan geçiyor. Aile olmanın da temel kriteri insanlara dokunmak, herkesin derdini anında hissedebiliyor olmanız. Bizde gerçekten bu var." (Organizasyonel Marka Stratejisi) (K5)

"Bir ticari karlılık bekleyerek yapıldı̆̆ı zaman yapılacak bir iş değil. Aynı kapitali başka bir işe koyduğunuz zaman hiçbir şey yapmayın sadece günümüzdeki kurumsal bankacılık uygulamalarından bile hiç risk almadan çok daha iyi getirilere sağlayabilirsiniz. Bunu çok açık yüreklilikle söylüyorum. Dolayısıyla burada bizim sıkıntımız şu geçmişten gelen o mahalle kültürü ile birlikte çalışan kültürü içerisinde... Manevi tatmin sağlıyoruz. Çünkü işin niteliği o. Toplumsal hafizamızın kopmaması gerekiyor." (Marka İsim Stratejisi) (K5)

"En iyi bildiğgimiz işi yapıyor olmak, nesiller arası aktarıma önem vermek, tüm taraflar ile etkin bir iletişime sahibiz, kalite var." (Marka Yayma Stratejisi) (K6)

"Farklılık ve girişimcilikle ortaya çıkmayı..."(Ar-Ge Stratejisi) (K6)

“Zamanmmz hastalılarından biri. franchise. Yani bayilik verme... Biz bu konuyu masaya yatırdık... Sürekli yenilenen kafalar, teknoloji, ürünler vb. inanın biz bunu yıllarca düşündük ve hiçbir zaman bayilik verelim mantığına çıkamadık. Çünkü şöyle düşündük: bu bizim sonumuz da olabilir. Şu anda biz 5-6 mağaza ile ilerliyoruz. Yarın öbür gün yanlışlıkla 10 bayilik verdiniz 3'ü işi bilmiyor. İnsanları kırıyor, tüketiyor. Dijital ortamda birleri bir şey yazdı, karaladı falan bize yansır bu; bizim de gardımız düşer, heyecanımız tükenir. Şubeleşme son 20 yılda olmaya başladı. Bu esnada şehrimizde büyümeye başladı. Bizim şehrimiz 18-20 yıl önce nüfusu 300.000 iken şimdi 1 milyona yaklaştı. Yani 2-3 yılda bir biz şu bölgeye yer açmamız gerekiyor diyoruz zaten. Şunu diyoruz önce biz kendi bahçemizde şey yapalım. Ama şehir dişından bizden talepleri cevaplamak için 12 yıl önce e-ticaret sitesi kurduk ve şu anda çok aktif, hareketli bir şekilde onu uyguluyoruz. Türkiye'nin çeşitli yerlerine bizim sevkiyatlarımız var." (Organizasyonel Marka Stratejisi) (K7)

“Bu noktada müş̧eri memnuniyeti çok önemli. Çıkardığınız ürünleri hep aynı şekilde aynı kalitede güvenilir bir biçimde yaparsanız; bu durum markayı çok uzun yıllar yaşatma şansı veriyor... O konuda müşterilerimiz ile iletişimimiz çok iyi. Herkes burayı evi gibi görüyor ve çok rahat bir şekilde eleştiriyor. Buraya bir ticaret merkezi gibi bakmıyor. Çünkü burada herkesin anıları, hikâyeleri var... Şubeleşmeyi bu yüzden istemedik, aynı kalitede yürütemeyebiliriz diye düşündük. Ancak pandemi süreci bizi farklı notlara getirebilir." (Marka İsim Stratejisi) (K8)

"Müşteri memnuniyetine önem vermek. Son kullanma tarihi yakınlaşan bir ürünü müşteriye vermek yerine gerekirse at çöp olsun. Bizim reklamımızı yapan kişiler zaten halktan insanlar. Bizi beğendikleri için kalite için reklamımızı yapıyorlar. Kaliteli yaptıkça, insanların beğenisini kazandıkça bu markanın devamlılığını sağlıyor." (Marka İsim Stratejisi) (K10)

"1944 yılında yediğim yemekte hangi tadı, lezzeti aldıysam; şu anda aynı tadı, lezzeti alıyorum dedi." (Marka İsim Stratejisi) (K11)

“K12'yi K12 yapan tek şey 'tek merkez, tek kalite ve tek usta' ondan dolayı bu bizim için çok önemli...Biz parasal yönüne bakmıyoruz. Ondan dolayı içimiz rahat. Ürünümüzün kalitesi iyi olsun zaten çok fazla ürüne girmiyoruz tek çeşit ürünümüz var. Ürün ve kalite bozulmasın. Ona gidiyoruz. Ondan dolayı kaliteden ödün vermeme adına onlarla bu sisteme devam etmeye çalışıyoruz." (Marka İsim Stratejisi) (K12) 


\section{H. Doğruöz Özer - E. Akagün Ergin 13/2 (2021) 1781-1799}

\subsection{Katılımcıların Kurumsal Markanın Güçlendirilmesinde Yenilikçiliğin Rolü Hakkındaki Görüşleri}

Araştırmanın çalışma grubunu oluşturan katılımcıların kurumsal markanın güçlendirilmesinde yenilikçiliğin rolü hakkındaki görüşlerine ait bulgular Tablo 5.'te verilmiştir.

Tablo 5. Kurumsal Markanın Güçlendirilmesinde Yenilikçiliğin Rolü Hakkındaki Görüşleri

\begin{tabular}{|l|l|l|}
\hline Kategori & Yenilikçi Stratejiler & \\
\hline & Tema & $\mathbf{f}$ \\
\cline { 2 - 3 } & Ar-Ge Stratejisi & 7 \\
\cline { 2 - 3 } & Teknoloji Stratejisi & 7 \\
\cline { 2 - 3 } & Finansal Strateji & 1 \\
\cline { 2 - 3 } & Pazarlama Stratejisi & 4 \\
\cline { 2 - 3 } & Marka Yayma Stratejisi & 3 \\
\cline { 2 - 3 } & Marka İsim Stratejisi & 1 \\
\hline
\end{tabular}

Tablo 5.'e göre katılımcıların kurumsal markanın güçlendirilmesinde yenilikçiliğin rolü hakkındaki görüşleri bir bütün olarak ele alındığında işlev ve kavram yönüyle bir kategori olarak değerlendirilmiştir. Bu kategori; Yenilikçi Stratejiler (23)'dir.

Yenilikçi Stratejiler (23) kategorisinin temalarına ait katılımcı cevaplarından bazı örneklere aşağıda yer verilmiştir:

"Yenilikleri yakından takip ediyoruz. Fabrika aşamasında olsun, satış kanalları olsun. Pandemi sürecinde gördük ki online satış önü alınamayacak bir şey. Bu süreçte web sitemizi yeniledik ve farkı gerçekten gördük. Bu durum özünden sapacak bir durum olmadığı içıin kanal dağıtımı açısından özünden sapmadan yeniliklere her zaman açı̆̆ız. Çok geleneksel bir firmayız ancak çă̆ın yeniliklerine ve insanların ihtiyaçlarına göre yenilikler yapmak gerekiyor." (Ar-Ge Stratejisi; Teknoloji Stratejisi; Finansal Strateji) (K1)

"Markanın güçlendirilmesinde yenilikçiliğin rolü ana roldedir. Çünkü bir süre sonra şuna dönüşüyorsunuz; biz iyiyiz niye çünkü biz bu işi çok eskiden beri yapıyoruz. Tamam ama bir noktadan sonra işi iyi yapacağınıza ya da başkasının sizden daha iyi yapmayacă̆g ile ilgili bir şey söylemiyorsunuz. Ancak bunu sürdüren yenilik. Bizim aslında sürekli yapmaya çalıştı̆̆ımız şey müşteriden bilgi toplamak. Müşteri ihtiyaçları ile ilgili olarak sürekli data topluyoruz. Müşterilerimiz çok kozmopolit. Bizim işletmemize bir memurda geliyor, yoldan geçende geliyor, sanatçıda geliyor, bir savcıda geliyor, bir bürokratta geliyor, diplomatta geliyor, ünlüde geliyor, ünsüzde geliyor, çok zengin bir iş adamı da geliyor. Yabancı müşterimiz de var yerli müşterimiz de var. Aynı şeyi tüketenler arasında bir kültür oluşmuş. 2020 yılında sadece kasadan müşteri datası topluyorum, bana otobüs çarpsa ne olacak ya da orada veri toplayan iki üç kişiye bir şey olsa ne olacak. Kurum hafizası bu olmamalı. Biraz alman disiplini gibi aslında orada her şeyin belgelenmesi. Bir sonraki nesle yazılı bir şekilde bırakılması. Kurumsallaşma dediğimiz şey bu aslında. Kurumsallaşma kimsenin birbirinden haberdar olmadığı şekilsel bir şey değgildir; ölçülebilir, aktarılabilir, takip edilebilir halde sisteme oturtulmasıdır." (Ar-Ge Stratejisi; Pazarlama Stratejisi) (K2)

"Sadece yaptığımız değişiklikler neyi daha iyi yapabiliriz noktasındayız. Bir tek onun üstüne doğru gidiyoruz...biz fiyat noktasında asla ve asla rekabet edemeyiz. Çünkü prensiplerimiz, o ahlaki değerler bunu bize müsaade etmez. Köşeleri dönmek daha ucuz versiyonunu yapmak. Bizim değerimiz; bunu devam ettirmek. Bundan daha iyi ne yapabiliriz?" (Pazarlama Stratejisi) (K3)

"Mesela 30 yıl önce ürettiğimiz ambalaj devam etmiyor. Bugün ambalaj değişerek geldi. Tüketici ihtiyaçlarını belirlemek gerekiyor." (Ar-Ge Stratejisi) (K4)

"Açıç̧ası onu bile şöyle yapıyoruz. Mesela diyoruz ki; Türk toplumuna özel kalmasın bu. Dünya Gıda Fuarlarna katılmayı arzuluyoruz. National Geografic geldi ve üretim yerimizde bir çekim yaptı. BBC geldi bir çekim yaptı. Yenilikçilik anlamında bunlar bizi motive ediyor. Insanlara bir ilham kaynăğ olunca. Biz tabi bunu yaparken o eski haliyle 7. yy'daki saçlara döküm hali ile gösterince o geleneğin korunmuş olması yani biz 'modernliğe geleneği taşıyoruz aslinda'" (Pazarlama Stratejisi; Marka Yayma Stratejisi) (K5)

"Ekleri geleneğinden koparmadan güncelleştirerek yenilik katıtı. Bunu bu şekilde yaptı̆̆ımız zaman aynı geleneksel ürünü koruyarak yenilikçiliği sağlamış oldum ve markayı da güçlendirdim. Şu an İstanbul'da ekler denilince ilk akla 


\section{H. Doğruöz Özer - E. Akagün Ergin 13/2 (2021) 1781-1799}

gelen markalardan bir tanesiyiz. Bu şekildeki yenilikçiliği önemsiyorum. Mümkün olduğu kadar özünden korkmadan odaklanmayı da kaçırmadan mutlaka yapılması gerektiğini düşünüyorum." (Marka Yayma Stratejisi) (K6)

"Birden beşe kadar bir şablon kurarsak yenilikçiliğin rolünü ikinci sıraya koyabilirim. Ürünün kendisindeki değişimden, yenilikçiliğinden, ambalajından hatta mağazanın çantasından hatta müşteriye verdiğiniz slipin tasarımına kadar tutun yenilikçilik iki numarada yer alır. Benim şöyle bir taktiğim var diyeyim; çok tuhaf bir saatte gece saat 1:00'de aklıma bir şey gelir. Hemen telefonumu çıkarırm, aklıma gelen şeyi not alırm. Çünkü sonra unutabiliyorsunuz, bunu şeye benzetirim. Bir bestekârın beste yapma durumu gibi o anda bir his gelir o adama ya da kadına onu melodiye döker ya da şiirsel söze döker ama sonra farklı haliyle unutur. Biz bunlar not alırı hep bunlarn hepsini aynı anda piyasaya veremiyorsunuz zaten çok tehlikeli bir şey yenilik adına saçma şeyler yapmakta doğru değil zaten. Yenilikçilik o kadar hassas bir nokta ki hem çok önemli hem de kullanmayı bilmeniz lazım. Çünkü ters tepme de olabiliyor." (Ar-Ge Stratejisi) (K7)

"Son zamanlarda sosyal medyayı, yazılı ve görsel basını çok fazla kullanıyoruz. Eskiden bu platformlar yoktu. Önceden rezervasyon sistemi ile çalışmıyorduk burada herkes pat diye gelip burada yemeğini yiyip gidiyordu. Şimdi rezervasyon sistemine döndük. Çünkü insanlar bunu talep etti ve Amerika'dan misafir getirdik yer yok gibi şikayetler gelmeye başlamıştı. Dijital platformlardan da yararlanıyoruz. Ancak yemek kısmına gelince çok fazla yenilik katmadan, eski unutulmuş yemekleri de ara ara menümüze dahil ederek uygulamalar yapıyoruz." (Ar-Ge Stratejisi; Teknoloji Stratejisi) (K8)

"Yenilik bir sonraki nesil için şöyle ben bunu baya yaşamış biri olarak söylüyorum kuşak çatışmasına düşmeden, sizden önceki neslin söylediklerini düzgün harmanlayıp düzgün anlayıp sonra bunları beyninizde bir kar yumă̆ı yapıp ondan sonra kardan adamınız yapmanız gerekiyor." (Ar-Ge Stratejisi) (K9)

"Mümkün mertebe şu anki teknolojilerden istifade etmek lazım, gerisinde kalmamak lazım. Onu da gerek sosyal medya da yer alarak gerek diğer reklam konusunda her türlü şeye açı olmak gerekiyor. Takip etmek lazım. Biz de bu mecralarda aktif olmaya çalışıyoruz." (Teknoloji Stratejisi) (K11)

"Sosyal medya kullanımı noktasında yenilikçiliği kullanıyoruz. Çağımızın gündemi sosyal medyadır. Yani artık sosyal medya olmadan maalesef öyle bir zamana geldik ki insanlarmiz bu tür yemekleri sosyal medyadan takip ediyor. İster istemez bizde buna ayak uydurmak zorundayız." (Teknoloji Stratejisi) (K12)

\subsection{Katılımcıların Markalarını Güncel Tutmak İçin Yaptıkları Hakkındaki Görüşleri}

Araştırmanın çalışma grubunu oluşturan katılımcıların markalarını güncel tutmak için yaptıkları hakkındaki görüşlerine ait bulgular Şekil 6.'da verilmiştir.

Tablo 6. Katılımcıların Markalarını Güncel Tutmak İçin Yaptıkları Hakkındaki Görüşleri

\begin{tabular}{|l|l|l|}
\hline Kategori & Marka Güncel Tutma Stratejileri & \\
\hline \multirow{3}{*}{} & Tema & f \\
\cline { 2 - 3 } & Ar-Ge Stratejisi & 9 \\
\cline { 2 - 3 } & Teknoloji Stratejisi & 9 \\
\cline { 2 - 3 } & Pazarlama Stratejisi & 4 \\
\cline { 2 - 3 } & Marka Yayma Stratejisi & 4 \\
\hline
\end{tabular}

Tablo 6.'ya göre katılımcıların markalarını güncel tutmak için yaptıkları hakkındaki görüşleri bir bütün olarak ele alındığında işlev ve kavram yönüyle bir kategori olarak değerlendirilmiştir. Bu kategori; Marka Güncel Tutma Stratejileri (26)'dir.

Marka Güncel Tutma Stratejileri (26) kategorisinin temalarına ait katılımcı cevaplarından bazı örneklere aşağıda yer verilmiştir:

"Yurtdışı fuar katılımları, sosyal medya kullanımı, teknoloji ve üretimdeki yenilikleri takip ederek markamızı güncel tutuyoruz." (Ar-Ge Stratejisi; Teknoloji Stratejisi) (K1)

"Markamızı müşteri ihtiyaçları ile ilgili olarak data toplayarak, yenilikçiliği önceliklerimiz arasında ilk sıraya koyarak, tüm müş̧eri segmentlerine hitap edecek ürünler üreterek markamızı güncel tutuyoruz." (Ar-Ge Stratejisi) (K2)

"Müşteri geri bildirimleri ve sosyal medya kullanımı ile markamızı güncel tutuyoruz." (Ar-Ge Stratejisi; Teknoloji 
Stratejisi) (K3)

"Sosyal medya kullanımı, müşteri geri bildirimlerine hızh geri bildirimlerde bulunma. Güncel ihtiyaçlara göre yeni ürünler geliştirme. Bir misafir geldi ise kapıda karşıladım. Mutlak suretle indim, şundan korktum bir zengin geldi başkan geldi de ona indi bana inmedi denmesin diye. Bunlar bile markayı etkiler, bilinçaltına yerleşen şeyler. Bunların hepsi inanmak, çok çalışmak, herkesle bütünleşmek, eksiği kendimizde görmek, bir başkasında hata bulmamak gibi kendimize has bir duruşumuz var." (Ar-Ge Stratejisi; Teknoloji Stratejisi; Pazarlama Stratejisi; Marka Yayma Stratejisi) (K4)

“...ürünü hazır tutarsanı. Yani insanlar sene de bir gün bizim ürünümüzü talep ediyor. Her kullanıcı genelde bir kez kullanır. O bir kez sene de bir gündür onun için. Gittiğinde rafta bulabiliyorsa tamam diyor. Bu ipin kopmamasın sağlayan şey. Diyoruz ki biz Türk toplumuna özel kalmasın bu. Dünya Gıda Fuarlarına katılmayı arzuluyoruz." (ArGe Stratejisi; Pazarlama Stratejisi; Marka Yayma Stratejisi) (K5)

"Benim biraz daha fazla yapmaya çalıştığım şimdi gençleri daha çok dahil etmeye çalıştığım sektörel derneklerde bulunmak, iş adamları derneklerinde bulunmak, yurtiçi ve yurt dışı fuarlara katılmak, internet ve sosyal medyayı kullanmak güncellemeyi sağlıyor." (Ar-Ge Stratejisi; Teknoloji Stratejisi; Marka Yayma Stratejisi) (K6)

"Biliyorsunuz çok fuar oluyor. Yöresel fuarlar oluyor, turistlik fuarlar oluyor... Gidicez markamızın büyüklüğ̈̈nü, eskiliğini, güvenilirliğini hissettireceğiz. Ürünlerimizi test ettireceğiz. Alışveriş yapmak isteyene de e-ticaret broşürlerimizi vereceğiz. Oradan alışverişlerini güvenli bir şekilde yapacaklar. Bunu kullanıyoruz. Yani nokta atış bizim işimize yarayacak fuarları kullanıyoruz. İkincisi sosyal sorumluluk projeleri... Sosyal medyayı da kullanıyoruz, bizim bölgesel internet haber siteleri, normal gazetelere reklamımızda oluyor. Sosyal sorumluluklarda yer alıyoruz, fuarlara da katıllyoruz." (Ar-Ge Stratejisi; Teknoloji Stratejisi; Pazarlama Stratejisi; Marka Yayma Stratejisi) (K7)

"Sosyal medyayı, yazılı ve görsel basinı kullanarak markamızı güncel tutuyoruz." (Teknoloji Stratejisi) (K8)

"Günümüz şartlarını talip ederek, müşteri ihtiyaçların iyi analiz ederek, piyasayı düzgün okuyarak yenilik yaparak markamızı güncel tutuyoruz." (Ar-Ge Stratejisi; Pazarlama Stratejisi) (K9)

"Markamızı güncel tutmak için sosyal medyadan yararlanıyoruz. Benimde ilk işim instagram ve facebook açmak oldu." (Teknoloji Stratejisi) (K10)

“Teknolojik gelişmeleri takip ederek ve sosyal medya da yer alarak markamızı güncel tutuyoruz." (Teknoloji Stratejisi) (K11)

"Sosyal medya, TV programlarında yer alma ve müşteri geri bildirimleri ile markamızı güncel tutuyoruz." (Teknoloji Stratejisi; Ar-Ge Stratejisi) (K12)

\subsection{Katılımcıların Markaların Güvenilirliği İçin Aldıkları Önlemler Hakkındaki Görüşleri}

Araştırmanın çalışma grubunu oluşturan katılımcıların markaların güvenirliliği için aldıkları önlemler hakkındaki görüşlerine ait bulgular Tablo 7.'de verilmiştir.

Tablo 7. Katılımcıların Markaların Güvenilirliği İçin Aldıkları Önlemler Hakkındaki Görüşleri

\begin{tabular}{|l|l|l|}
\hline Kategori & Marka Güvenirliliğine Yönelik Stratejiler & \\
\hline & Tema & $\mathbf{f}$ \\
\cline { 2 - 3 } & Ar-Ge Stratejisi & 4 \\
\cline { 2 - 3 } & Pazarlama Stratejisi & 9 \\
\cline { 2 - 3 } & Organizasyonel Strateji & 1 \\
\cline { 2 - 3 } & Teknoloji Stratejisi & 4 \\
\cline { 2 - 3 } & Marka İsim Stratejisi & 11 \\
\hline
\end{tabular}

Tablo 7.'ye göre katılımcıların markaların güvenilirliği için aldıkları önlemler hakkındaki görüşleri bir bütün olarak ele alındığında işlev ve kavram yönüyle bir kategori olarak değerlendirilmiştir. Bu kategori; Marka Güvenirliliğine Yönelik Stratejiler (29)'dir.

Marka Güvenirliliğine Yönelik Stratejiler (29) kategorisinin temalarına ait katılımcı cevaplarından bazı örneklere aşağıda yer verilmiştir: 


\section{H. Doğruöz Özer - E. Akagün Ergin 13/2 (2021) 1781-1799}

"Bu aslında üretim zamanından başlıyor. Çok sık kontrol yapıyoruz. Çünkü kalite kontrole önem veriyoruz. Numune kontrolü....Gelecek bir şikâyet veya öneri için bu numuneleri tutmak çok önemli. Çünkü müşteriler arryor ve diyor ki bu aldığım lokumlar geçen sene aldığım gibi değil, üç gün önce aldığım gibi değil diyor. Numunelerin kaydını tutup numaralandırdı̆̆ımız için bulabiliyoruz. Kayıt tutmak ve numune almak üretimdeki en önemli nokta diyebilirim. Şu anda sosyal medya da herkesin ulaştı̆̆ l bir alan oradan da çok güzel geri bildirim geliyor... geri bildirime çok açık bir firmayız. Çok büyük olmadığımız için yani geri bildirimler birkaç etaptan geçip ilgili yere gitmediği için gelip doğrudan değerlendirildiğinden çabuk işleme koyuyoruz. Güvenilirlik için en önemli iki şey kalite kontrol ve geri bildirim diyebilirim." (Ar-Ge Stratejisi; Pazarlama Stratejisi; Organizasyonel Strateji; Teknoloji Stratejisi) (K1)

“Güvenlik 360 derece bir şey. Ürün kalitesini kontrol etmek için ürünün hammadde, hijyen güvenliği vb. dünyada İSO gibi standardize etmek isteyen kuruluşlarda var. Bunları aldık ama zaten yapıyorduk güvenlik önlemlerini. Markanın taklitleri vb. şeylerde hukuki boyutu var aldığımız danışmanlıklar ile bir takım güvenlik önlemleri almaya çalışıyoruz ama buradaki en önemli güvenlik bizde şimdi marka kimlik yenileme çalışmaları devam ediyor. 1 ay içerisinde marka kimliği, logosu hepsinin değişmesi söz konusu. O kısmı toparlıyoruz. Sadece ürün sunmak bir şey ifade etmiyor....Taklit edilemeyecek olan şey şu sizin marka hikâyeniz ve kurduğunuz iletişim...Markanın da asıl koruma sağlaması bununla olur. Kendi hikâyesi ve ona uygun görselleriyle. Ben Gaziantep'ten gelmiş gelenek ve yeniliği harmanlamış bir firmayım. Ben diyorum ki gelenek ve yenilik arasında dünyaya açlan bir köprüyüm....Hikâye ile anlatım bir taklit edilebilirliği azaltıyor ikincisi on tane şey söylemeden içinden bir iki şeyi seçip onun üzerinden gitmek. 2021 de sağlayabileceğimiz bu. Daha önceden yoktu değil işte daha tutarl ve tek elden gitmiyordu. Teknolojide buna imkân tanıyor tabi ki. Bir sürü elimizde imkân var." (Ar-Ge Stratejisi; Pazarlama Stratejisi; Marka İsim Stratejisi; Teknoloji Stratejisi) (K2)

"İ̧sletmede çalışırken günümün yüzde 5'i google yorumlarnnda tripadviser yorumlarında geçiyor. Çünkü eleştirileri alıp kendimizi düzeltme imkânımı oluyor. Müşteriyle bireysel diyaloğa girerek şöyle yapalım böyle yapalım gibi anında müdahale ediyoruz. Müşteri olarak bu kültürün bir parçası... Yeni nesilde, teknolojinin arttığı bu dönemde işlerimiz çok zorlaşmaya başladı. Çünkü bilgi çok çabuk dağıllıyor, çok çabuk geliyor ve hani o kimliği korurken de insanlarm bilmediği yüzlerini de görmek, insanların tahammülü de az, ince buzun üzerinde yürüdüğ̈̈müz bir zaman." (Pazarlama Stratejisi; Marka İsim Stratejisi; Teknoloji Stratejisi) (K3)

"Güvenilirlik için en önemlisi olmazsa olmaz kalite, sonra en ufak bir şikâyette derhal cevap vermek, güvenilirliği sağlamak. Mesela satış yaparsını müşteri şunu bilir ki K4 doğru fatura keser, K4'e sözle bile sipariş verdiyseniz sonradan değişen fiyat vb. gibi şeylerden etkilenmeden eski fiyatından K4 ürünleri verir. En büyük güven budur. Siz bir söz verdiniz o sözü yerine getirmek zorundasınız. İsterse milyar kazandırsın isterse milyar kaybettirsin hiç önemli değil." (Pazarlama Stratejisi; Marka İsim Stratejisi) (K4)

"Ticarette her bir faaliyetiniz, her bir muhatabını ile ilişkiniz sizin genel olarak bütün markanıza olumlu veya olumsuz bir etki yapabiliyor. Mesela tedarikçiler var, mal sahipleri var, çalışan var, müşteriler var, ortak var, evdekiler var, komşular var. Bunların hepsi ile aslında çok doğru bir iletişim kurmanız gerekiyor. Bu iletişim her zaman açık net ve doğru olmak zorunda... Oradaki o mesafeyi koruyarak sevgi ve saygıyı da koruyarak yaptığınızda şu ana kadar bizim işte çalışan sayısına baktığımızda değişim hızı çok fazla olmamakla birlikte bir tane çalışanımız ile bile mahkemelik olmadık. Bu da çok önemli bir şey. Müşteri nezdinde bakttğınızda müşteriyle mahkemeliğimiz şikâyetimiz olmadı. Gıda üreticisi olduğumuz için tabi ki de üründe sorun çıkabiliyor. İlişki yönetimi ile müşteriye samimi olarak davrandı̆̆ımızda öyle şeyler oluyor ki müşteri bizden aldı̆̆̆ üründen şikâyetçi olduktan sonra şikâyetçi olmadığı haline göre çok daha iyi bir müşteri olarak dönüyor. Neden? Çünkü ilgi gösterdiğimizden dolayı. Ona dürüst davrandığımızdan dolayı." (Pazarlama Stratejisi; Marka İsim Stratejisi) (K6)

"Siz tüketiciye mağazadan alsın çıksın. Mağazada sorunumuz olmasın, dışarıda ne olursa olsun gibi bir mantık ile hareket ederseniz kimse size güvenmez. Biz şöyle düşünüyoruz: alı̧̧verişini yaptl, götürdü, yedi. Viral olarak biri birine anlatsin istiyoruz. Güvenilirliği ancak düzgün, lezzetli ürünler üretip sürecin sonuna kadar takip ederek sağlayabilirsiniz." (Pazarlama Stratejisi; Marka İsim Stratejisi) (K7)

\footnotetext{
"Markanın güvenilirliğini sağlamak için gece-gündüz peşini bırakmıyoruz. Her zaman takipçisiyiz...Nasıl daha iyi olabiliriz, nasıl daha faydah olabiliriz, nasıl daha konuğumuzu misafirimizi daha iyi bir şekilde ağırlayabiliriz. Biz gelen konuğumuza hiçbir zaman müşteri gözüyle bakmayız her zaman misafir ve konuk olarak düşünürüz. Böyle öğrenmişiz öyle de devam ettiriyoruz...Türkiye'de A kalite mal nerede varsa oradan mal alıyoruz. Bizde idare eder mantığı yoktur. Sebzesinden meyvesine, meyvesinden etine, etinden bakliyata her ne alırsak alalım...Müşteri geri bildirimleri de bizim için çok önemli." (Ar-Ge Stratejisi; Pazarlama Stratejisi; Marka İsim Stratejisi) (K11)
} 


\subsection{Katılımcıların Markalarının Sembolü, Anlamı ve Kurulduğundan Beri Değişiklik Olup Olmadığı Konusu Hakkındaki Görüşleri}

Araştırmanın çalışma grubunu oluşturan katılımcıların markalarının sembolü, anlamı ve kurulduğundan beri değişiklik olup olmadığı konusu hakkındaki görüşlerine ait bulgular Tablo 8.'de verilmiştir.

Tablo 8. Katılımcıların Markalarının Sembolü, Anlamı ve Kurulduğundan Beri Değişiklik Olup Olmadığı Konusu Hakkındaki Görüşleri

\begin{tabular}{|c|c|c|c|c|}
\hline Kategori & $\begin{array}{l}\text { Markalarının Sembolü ve } \\
\text { Anlamında Değişiklik Olanlar }\end{array}$ & & $\begin{array}{l}\text { Markalarının Sembolü ve Anlamında } \\
\text { Minumum Düzeyde Değişiklik } \\
\text { Olmayanlar }\end{array}$ & \\
\hline & Tema & $\mathrm{f}$ & Tema & f \\
\hline & $\begin{array}{lll}\text { Teknoloji } & \text { Stratejisine } & \text { Yönelik } \\
\text { Değişiklikler } & & \\
\end{array}$ & 7 & Marka İsim Stratejisinin Korunması & 4 \\
\hline & $\begin{array}{l}\text { Marka Yayma Stratejisine Yönelik } \\
\text { Değişiklikler }\end{array}$ & 3 & & \\
\hline & $\begin{array}{l}\text { Marka İsim Stratejisine } \\
\text { Değişiklikler }\end{array}$ & 2 & & \\
\hline
\end{tabular}

Tablo 8.'e göre katılımcıların markalarının sembolü, anlamı ve kurulduğundan beri değişiklik olup olmadığ1 konusu hakkındaki görüşleri bir bütün olarak ele alındığında işlev ve kavram yönüyle bir kategori olarak değerlendirilmiştir. Bu kategori; Markalarının Sembolü, Anlamı ve Kurulduğundan Beri Değişiklik Olanlar (12) ve Markalarının Sembolü, Anlamı ve Kurulduğundan Beri Değişiklik Olmayanlar (4)’dır.

Markalarının Sembolü, Anlamı ve Kurulduğundan Beri Değişiklik Olanlar (12) kategorisinin temalarına ait katılımcı cevaplarından bazı örneklere aşağıda yer verilmiştir:

"Marka da değişim logoda sembolde sürekli olmuş. Tipografi, yazı her şey geçmişten günümüze değişmiş...Bunlar hep işin görsel kısmındaki değiş̧iklikler. Görsel değişiklikler tek başına bir şey taşımıyor. Öyle olsa herkese görselini rengini değiştirir. Ne kadar çok yazarsanız daha çok anlaşılmıyor. Daha uzun iletişim kurduğunuzda anlaşıllyor. Dev markaların reklama ihtiyacımı mı var, yok gibi görünüyor ama var. O pazarları o imajları korumak için var. Insanların beyinlerinde sürekli tutmak için gerekli. Bugün biri gelir sizin yerinizi alır. Bugün aslında bunu yapmamızın nedeni bir noktada toparlama onu sağlamaya çalışıyor. İşin içine instagram girdi. Daha sade daha anlaşılır hale getirmek için yapıldı değişiklikler. "(Teknoloji Stratejisine Yönelik Değiş̧iklikler; Marka Yayma Stratejisine Yönelik Değişiklikler) (K2)

"Logomuzda değişiklik oldu. Bundan 13-14 yıl öncesine kadar logomuz Mardin taş evlerinin kemerlerinde, kapının üzerinde, taştan çiçek tarzında bir oyma hat, taş işçiliği ile yapılmış bir amblemimiz vardı. Sonra Mardin'de turizm artırınca bir sürü otel oldu, bir sürü pansiyon oldu bir baktık bizim logomuzdan yüzlerce yani uzaktan baktı̆̆ınızda herkes aynı logoyu kullanıyor gibi görünüyordu. O zaman logoda değişiklik yapmak kararı aldık." (Marka Yayma Stratejisine Yönelik Değişiklikler) (K7)

Markalarının Sembolü, Anlamı ve Kurulduğundan Beri Değişiklik Olmayanlar (4) kategorisinin temalarına ait katılımcı cevaplarından bazı örneklere aşağıda yer verilmiştir:

“Kurulduğu günden beri sembolümüzde bir değişiklik olmadı....Güzel de bence o dönem itibariyle mantıklı bir yapıya oturmuş....Bu çok primitive bir düşünce, ben şimdi baktı̆̆ımda da geçerli olduğunu görüyorum bunun. Daha modern olmasina gerek yok. (Marka İsim Stratejisinin Korunması) (K5)

"Sembol ve logo kurulduğundan beri aynı şekilde değişiklik olmadı." (Marka İsim Stratejisinin Korunması) (K12)

\section{SONUÇ VE TARTIŞMA}

Marka mirasına sahip firmaların ortak stratejileri ve söylemleri ele alındığında öncelikle marka mirasına sahip firma temsilcilerinin salt ticari bir güdüyle hareket etmediğini önceliklerinin markalarının devamlılığı olduğu ayrıca ülke kültürünü tanıtma şeklinde daha büyük bir misyon edindikleri anlaşılmaktadır. Marka mirasına 


\section{H. Doğruöz Özer - E. Akagün Ergin 13/2 (2021) 1781-1799}

sahip firma temsilcilerinin markayla bütünleştiği markalarını bir yaşam biçimi haline getirdiği, marka mirasına sahip firma temsilcilerinin çalışanlar ile bağının güçlü olduğu bulgular arasında yer almaktadır. Marka özünü korumak amacıyla mevcut sektörlerinden, yaptıkları işten uzaklaşmadıklarını, yenilikleri geleneklerden vazgeçmeden gerçekleştirdiklerini ifade etmişlerdir. Yenilikçilik bağlamında girişimci bir yapıya sahip oldukları, yeniliklerde öncü bir rol oynadıkları anlaşılmıştır. Teknolojinin hızlı gelişimine ve sosyal medya platformlarının kullanımına önem verdikleri, yapılan yeniliklerin çoğunlukla teknolojik yenilikler olduğu ve bu yeniliklerin marka özüne zarar vermeden yapıldığı görülmektedir. Ayrıca müşteriler, tedarikçiler vb. tüm taraflar ile iletişimlerine azami dikkat gösterdikleri analiz sonuçlarındaki bulgular arasındadır.

$\mathrm{Bu}$ çalışma sonucunda gıda sektöründe görüşme gerçekleştirilen 12 firma temsilcisinin ortak olarak ortaya koyduğu pazarlama stratejileri nitel veri analizi tekniği kullanılarak kodlanmış ve özetlenmiştir. Sonuçların bu şekilde sunumu marka mirası kavramının firmaların stratejilerinde kullanma biçimini sistemli bir şekilde pazarlama stratejileri ile ilişkilendirmesini sağlamıştır.

Yapılan görüşmeler ve değerlendirmeler neticesinde marka mirasına sahip firmaların en çok önem verdiği unsurlar; etik değerler, algılanan kalite, marka imajı, marka isim stratejisi, AR-GE stratejisi/teknoloji stratejisi, marka isim stratejisi ve teknolojisi stratejisi olarak sıralanabilir.

Çalışma sonucunda elde edilen bulgular literatürde daha önce yapılan çalışma sonuçları ile karşılaştırıldığında, daha önce yapılan çalışmalar ile uyumlu olduğu görülmüştür. Mevcut çalışmalarda da marka mirasına sahip firmalar için kalite, sürdürülebilirlik, yenilikçilik, müşteri memnuniyeti gibi kavramların önemli vurgulanmaktadır.

Çalışma sonucunda, işletme yöneticilerin marka mirası kavramına ve Urde ve diğg. (2007)'nin ele aldıkları beş boyuta göre marka miraslarını oluşturdukları ve onu iyi yönetmeleri ile başarılarına destek oldukları görülmüştür. Marka mirasına sahip firmaların kendi geçmiş performanslarının önemli olduğunun farkındalığı ile hareket ettikleri, tüketicilerin istek ve ihtiyaçlarının karşılandığı bunu yaparken marka özünden taviz verilmediği anlaşılmıştır, işletmenin tüketicilere verdiği sözleri ne olursa olsun güveni sağlama adına tuttuğu ve hizmet sunumunda tutarlı bir yol izlendiği tespit edilmiştir. İşletmelerin ticari karlılık bilincinden öte ulusal bir değer bilinci ile hareket ettikleri ve önceliklerini bu doğrultuda belirledikleri anlaşılmaktadır. İşletmelerin faaliyet sürelerine ilişkin mesajların tutundurma araçları ile verildiği ancak bu durumun işletmeleri rehavete sürüklemediği görülmüştür. Sembollerin kullanımı ile tüketiciler açısından riskin azaltılması bağlamında yararlanıldığı tespit edilmiştir. İşletmelerin temel değerler ve politikalarını belirlediği ve bir yaşam şekli haline getirerek marka ile bütünleştikleri anlaşılmaktadır. Ayrıca işletme çalışanları da markanın bir değeri olarak görülmektedir.

Balmer (2013) çalışmasında, ulusal sosyoekonomik, etik ve teknolojik ortamların kurumsal mirası temsil ettiğini belirtmektedir. Bu çalışma ile çalışma sonuçlarımız benzerlik göstermektedir.

Yıldız ve Koç (2017)'un çalışma sonucunda marka mirası ve marka güveninin satın alma niyeti, müşteri tatmini ve marka sadakati üzerindeki etkilerine dayanarak işletmelerin tüketiciler açısından; markaları adı altında bir değer oluşturmaları, vaatlerini gerçekleştirmeleri, dürüstlükten taviz vermemeleri, ürünlerle ilgili problemlere anında çözüm getirmeleri, ulusal zenginliğin bir parçası olduklarını vurgulamaları yönünde stratejiler oluşturmaları önerileri ile çalışma sonucunda marka mirasına sahip işletme temsilcilerinin ifadelerinin birbirini destekler nitelikte olduğu görülmektedir.

Schroeder J., Borgerson J. and Wu Z. (2015)'nin yaptıkları iki Çin markasını ele aldıkları çalışmalarında tüketici görüşlerini ortaya koymuşlardır. Çalışma sonucunda kurumsal marka mirasında; kalite, işçilik, değerler, marka, kültürel referanslar/geleneksel kültür kavramlarının kodlamalarda ön plana çıktığı görülmüştür. Tüketici bakış açısının ele alındığı bu çalışma ile de mevcut çalışmamızın sonuçları benzerlik göstermektedir. Çalışma sonuçlarında yaratıcılık kodlaması ön plana çıkmamış olmakla birlikte AR-GE Stratejisi altında bu durumun değerlendirilebileceği, marka özüne dokunmadan yenilik yapmanın temsilcilerin söylemleri de dikkate alındığında yaratıcılık gerektirdiği söylenebilir. Bundan sonra yapılacak çalışmalarda yaratıcılık unsurunun derinlemesine incelenmesi tavsiye olunur.

Balmer ve arkadaşları (2006) tarafından kurumsal miras markaları kavramının tanıtıldığı çalışmalarında, birkaç anahtar yönün bu kavramın temelini oluşturduğu ifade edilmiştir. Kurumsal miras markalarının; 


\section{H. Doğruöz Özer - E. Akagün Ergin 13/2 (2021) 1781-1799}

halkların ve yerlerin tanımlanmasındaki rolleri; markanın yenilenmesi ve yeniden inşası için markanın duygusal içeriği ve denge çekirdeği korunarak günümüze uygun değerlerin adapte edilmesi; kurumsal mirasın etkin yönetimi, markaların geçmişi şimdiki zamanla ve geleceği göz önüne alarak değişen dünyada sabit referans noktalarına sahip olması bu yönleri temsil etmektedir. Çalışma için belirlenen gıda firmalarının ve elde edilen sonuçların kurumsal marka mirası ölçütlerini destekler nitelikte olduğu görülmektedir.

Balmer, 2011 çalışmasında, kurumsal miras markalarını destekleyen üç temel ilke olduğunu belirtmektedir: Güven, özgünlük ve yakınlık (sempati). Güven, kurumsal marka ile paydaşlar arasındaki ikili güven ile ilgilidir. Özgünlük, kurumsal miras markalarının kalıcı kimlik özelliklerini koruma fikrini yakalar. Kamu egemenliği kavramını yakalar (herhangi bir kurumsal miras markasının dayanması için kamu rızası olması gerekir). Çalışma sonuçlarımızda etik değerlerin ve kalitenin vurgulanıyor olması güven unsuru ile, marka özünü koruma gayretlerine yönelik oluşturdukları stratejiler özgünlük unsuru ile, yakınlık (sempati) kavramı çalışma verilerimizden müşteri odaklılık sonuçları ile uyumludur.

Çalışmanın temel kısıtlılığı, sadece gıda sektöründe faaliyet gösteren ve 95 yıl üzeri firmaları kapsıyor olmasıdır. Balmer'in kriteri göz önüne alınarak 50 yıl üzerinde faaliyet gösteren firmalar ile benzer çalışmalar yapılabileceği gibi farklı sektörlerde benzer çalışmaların yapılması tavsiye olunur. Böylece tüm sektörleri kapsayan ya da sektörler özelinde marka mirası konusunda işletmelerin pazarlama stratejilerini destekleyecek bir model ortaya konulabilir.

\section{Kaynakça}

Aktepe C. ve Baş M. (2008). Marka Bilgisi Sürecinde Marka Farkındalığı ve Algılanan Kalite (Beklenti) İlişkisi ve GSM Sektörüne Yönelik Bir Analiz, Gazi Üniversitesi İktisadi ve İdari Bilimler Fakültesi Dergisi, Vol.10, Issue 1, sayfa 81-96.

Balmer, J.M.T., Greyser, S. and Urde, M. (2007). The crown as a corporate brand: Insights from monarchies. Journal of Brand Management, 14(1-2), 137-161.

Balmer J.M.T, (2011). Corporate heritage identities, corporate heritage brands and the multiple heritage identities of the British Monarchy, European Journal of Marketing, Vol. 45 Iss 9/10 pp. 1380 - 1398.

Balmer J.M.T, (2013). Corporate heritage, corporate heritage marketing, and total corporate heritage communications, Corporate Communications: An International Journal, Vol. 18 Iss 3 pp. 290 - 326.

Balmer J.M.T ve Chen W. (2017). Corporate heritage brands, augmented role identity and customer satisfaction, European Journal of Marketing, Vol. 51 Issue: 9/10, 1510-1521.

Bargenda A. (2015). Corporate heritage brands in the financial sector: The role of corporate architecture, Journal of Brand Management, Vol. 22, 431-447.

Baş M. (2015). Marka Kavramı, Tanımı, Önemi, Marka Yönetimi, Detay yayıncılık, Ankara, 45.

Bogdan, R. C., \& Biklen, S. K. (1998). Foundations of Qualitative Research in education. Qualitative Research in Education: An Introduction to Theory and Methods (3rd Edition), Allyn \& Bacon, Needham Heights, MA, $1-48$.

Cooper H., Merriles B. and Miler D. (2015). Corporate Heritage Brand Management: Corporate Heritage Brands Versus Contemporary Corporate Brands, Journal of Brand Management, 22 (3), 412-430.

Çiftçi S., Velioğlu M. ve Umut M. (2014). Marka Mirası Kavramı ve Hizmetlerde Marka Mirasına Yönelik Bir Ölçek Değerlendirmesi, Anadolu Üniversitesi Sosyal Bilimler Dergisi, 14 (1), 105-114.

Dion D. and Borraz S. (2015). Managing heritage brands: A study of the sacralization of heritage stores in the luxury industry, Journal of Retailing and Consumer Service, 22, 77-84.

Hudson, B.T. and Balmer, J.M.T. (2013). Corporate Heritage Brands: Mead's theory of the past, Corporate Communications: An International Journal, 18(3), 347-361.

Koç, E. (2017). Tüketici Davranışı ve Pazarlama Stratejileri, Seçkin Yayıncılık, Ankara.

Miles M.,\& Huberman M. (1994). Data Management and Analysis Methods, Sage Publications, Thousand Oaks, CA., 59-61. 
H. Doğruöz Özer - E. Akagün Ergin 13/2 (2021) 1781-1799

Patton, M.Q. (2002). Qualitative Research \& Evaluation Methods (3rd ed.), Sage Publications, Thousand Oaks, CA,17-21.

Santos F. P., Balmer J.M.T and Burghausen M. (2016). Heritage branding orientation: The case of Ach. Brito and the dynamics between corporate and product heritage brands, Journal of Brand Management, 23, 6788.

Schroeder J., Borgerson J. and Wu Z. (2015). A brand culture approach to Chinese cultural heritage brands, Journal of Brand Management, 22, 261-279.

Johnson, B., \& Christensen, L.B. (2004). Educational Research: Quantitative, Qualitative, and Mixed Approaches (2nd Edition), Pearson Education, Inc, Boston., 25-28.

Taşkın, Ç. (2018). Marka ve Marka Stratejileri, Dora Yayınevi, Bursa.

Thomas, J., \& Harden, A. (2008). Methods For The Thematic Synthesis of Qualitative Research In Systematic Reviews. BMC Medical Research Methodology, 8(45), 1-10.

Wiedmann, K.P., Hennigs, N., Schmidt, S. ve Wuestefeld, T. (2011). Drivers and Outcomes of Brand Heritage: Consumers' Perception of Heritage Brands in the Automotive Industry, Journal of Market Theory and Practice, Vol. 19, No. 2, 205-220.

Yıldırım, A., \& Şimşek, H. (2018). Sosyal Bilimlerde Nitel Araştırma Yöntemleri (10. Baskı), Seçkin Yayıncılık, Ankara, 217-218.

Yıldız E. ve Koç M. E. (2017). Marka Mirası ve Marka Güveninin Satın Alma Niyeti, Müşteri Tatmini ve Marka Sadakati Üzerindeki Etkileri, Dumlupınar Üniversitesi Sosyal Bilimler Dergisi, Pazarlama Kongresi Özel Sayıs1, 86-104. 